In cooperation with the Texas Parks and Wildlife Department

\title{
Compilation of Historical Water-Quality Data for Selected Springs in Texas, by Ecoregion
}

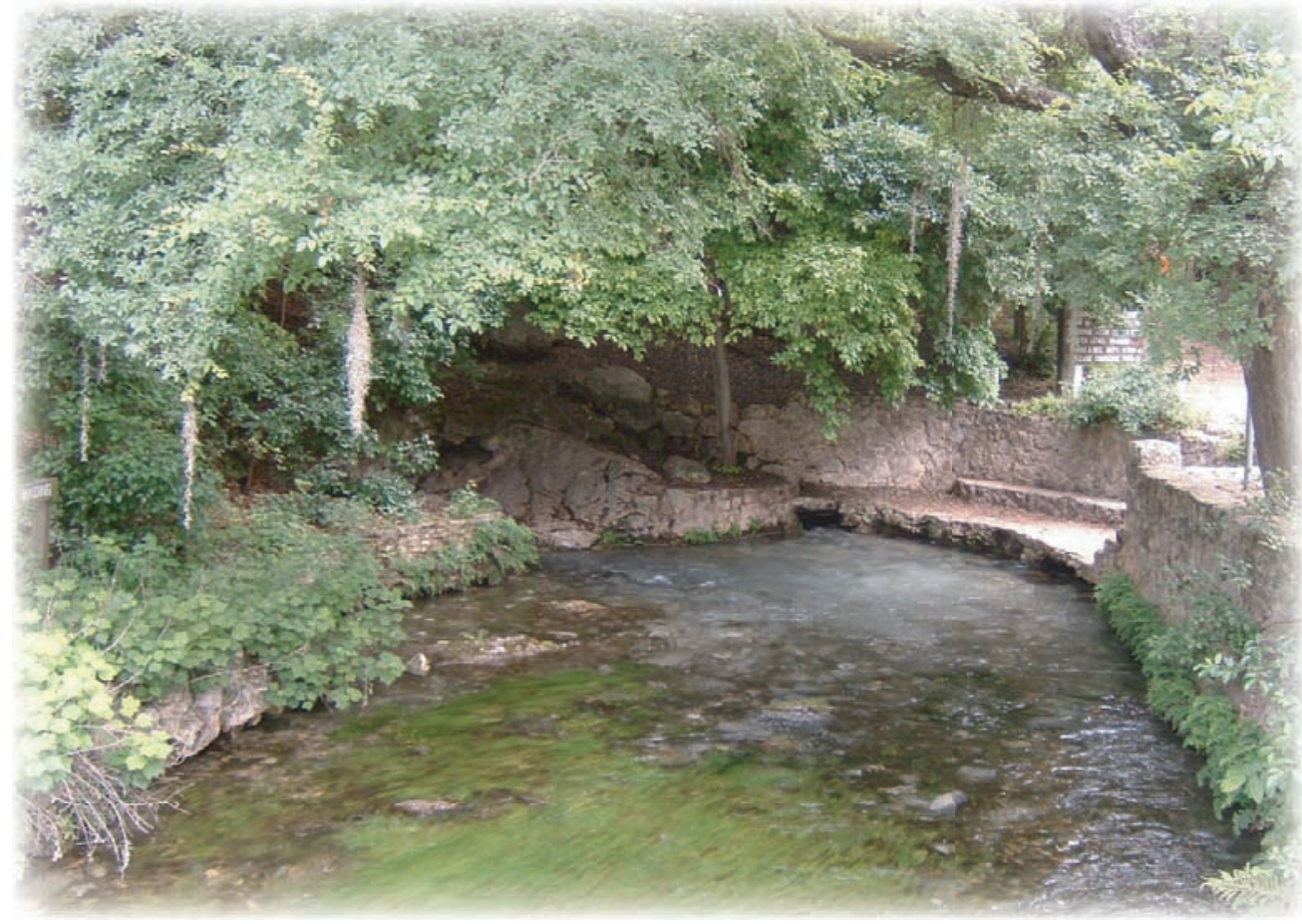

Data Series 230 
Cover. One orifice of Comal Springs in Landa Park at New Braunfels, Texas. 


\section{Compilation of Historical Water-Quality Data for Selected Springs in Texas, by Ecoregion}

By Franklin T. Heitmuller and Iona P. Williams

In cooperation with the Texas Parks and Wildlife Department

Data Series 230

U.S. Department of the Interior

U.S. Geological Survey 


\title{
U.S. Department of the Interior DIRK KEMPTHORNE, Secretary
}

\author{
U.S. Geological Survey \\ Mark D. Myers, Director
}

\section{U.S. Geological Survey, Reston, Virginia: 2006}

For more information about the USGS and its products:

Telephone: 1-888-ASK-USGS

World Wide Web: http://www.usgs.gov/

Any use of trade, product, or firm names in this publication is for descriptive purposes only and does not imply endorsement by the U.S. Government.

Although this report is in the public domain, permission must be secured from the individual copyright owners to reproduce any copyrighted materials contained within this report.

Suggested citation:

Heitmuller, F.T., and Williams, I.P., 2006, Compilation of historical water-quality data for selected springs in Texas, by ecoregion: U.S. Geological Survey Data Series 230, 32 p. 


\section{Contents}

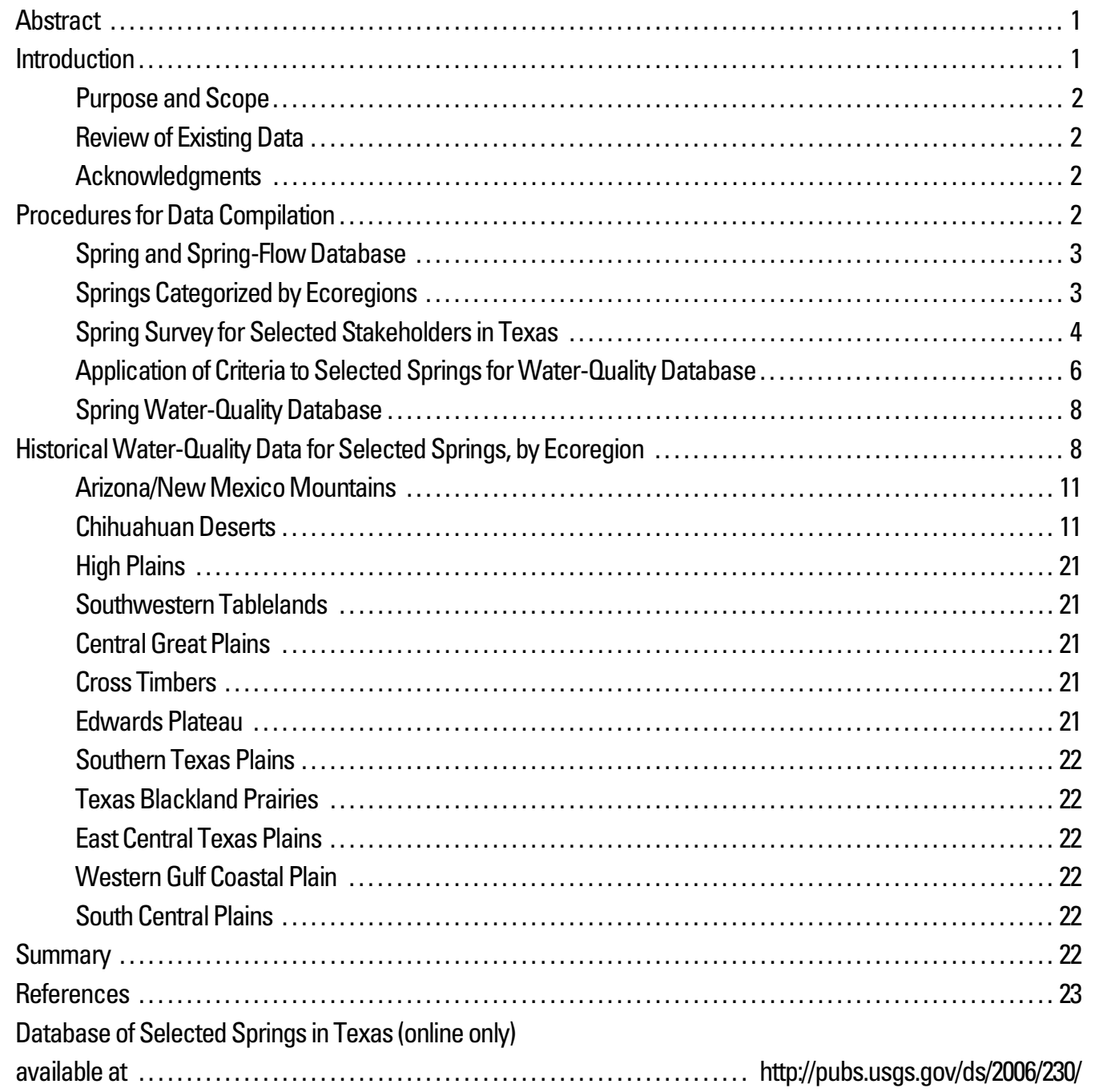

\section{Figures}

1. Map showing locations of selected springs in Texas ................................. 3

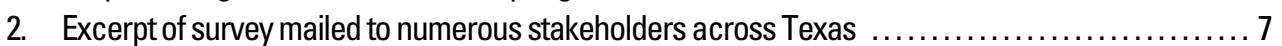

3-6. Maps showing:

3. Springs selected for inclusion in the water-quality database of springs in Texas,

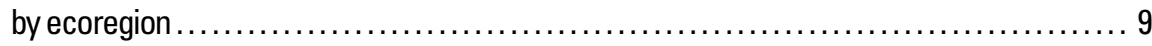

4. Major aquifers in Texas and springs selected for inclusion in the water-quality

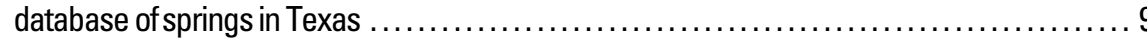

5. Minor aquifers in Texas and springs selected for inclusion in the water-quality

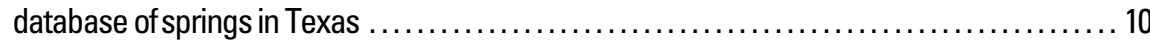

6. River basins in Texas and springs selected for inclusion in the water-quality database

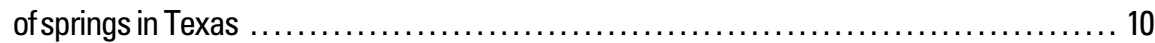

7. Screen capture of data-entry interface for water-quality database of springs in Texas ......... 11 
8-25. Maps showing:

8. Spatial distribution of 11,675 water-quality values for selected springs in Texas, by

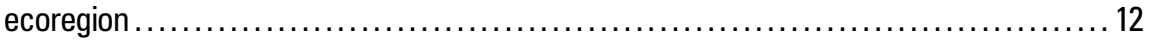

9. Range of median silica concentrations for selected springs in Texas, by ecoregion ....... 12

10. Range of median calcium concentrations for selected springs in Texas, by

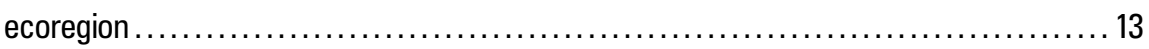

11. Range of median magnesium concentrations for selected springs in Texas, by

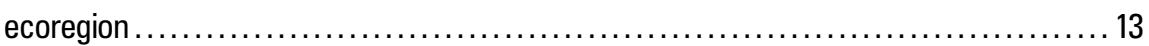

12. Range of median sodium concentrations for selected springs in Texas, by

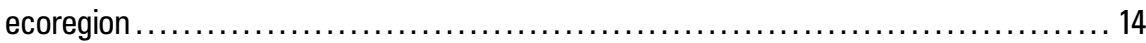

13. Range of median potassium concentrations for selected springs in Texas, by

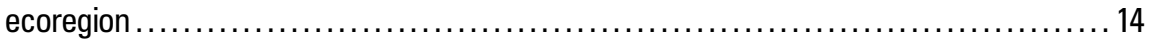

14. Range of median strontium concentrations for selected springs in Texas, by ecoregion

15. Range of median bicarbonate concentrations for selected springs in Texas, by ecoregion 15

16. Range of median sulfate concentrations for selected springs in Texas, by ecoregion 16

17. Range of median chloride concentrations for selected springs in Texas, by ecoregion 16

18. Range of median fluoride concentrations for selected springs in Texas, by ecoregion.....

19. Range of median nitrate nitrogen concentrations for selected springs in Texas, by ecoregion .

20. Range of median $\mathrm{pH}$ for selected springs in Texas, by ecoregion .................... 18

21. Range of median dissolved solids concentrations for selected springs in Texas, by ecoregion 18

22 Range of median alkalinity for selected springs in Texas, by ecoregion ................ 19

23. Range of median hardness for selected springs in Texas, by ecoregion ............... 19

24. Range of median specific conductance for selected springs in Texas, by ecoregion . ...... 20

25. Range of median temperature for selected springs in Texas, by ecoregion .............. 20

\section{Tables}

1. Number and percentage of total springs in database for Texas level III ecoregions

2. Largest springs in each Texas level III ecoregion on basis of mean spring flow for entire

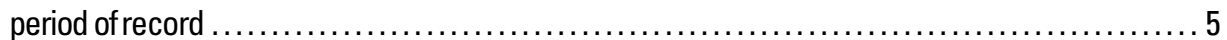

3. Largest springs in Texas on basis of mean spring flow for entire period of record .............. 6

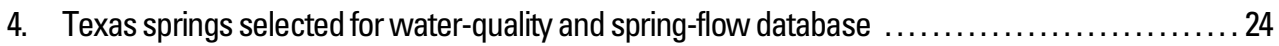

5. Number of values used to compute mean, median, and standard deviation of selected water-quality constituents and properties for selected springs in Texas, by ecoregion ..........29

6. Water-quality parameter codes and description of selected constituents and properties used in statistical summaries and maps for selected springs in Texas

7. Mean, median, and standard deviation values of selected water-quality constituents and properties for selected springs in Texas, by ecoregion

8. Minimum and maximum values of selected water-quality constituents and properties

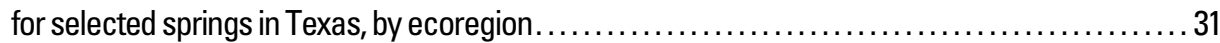

9. Water-quality standards of selected constituents and properties $\ldots \ldots \ldots \ldots \ldots \ldots \ldots \ldots \ldots \ldots \ldots \ldots \ldots \ldots \ldots \ldots \ldots$ 


\section{Conversion Factors and Datum}

SI to Inch/Pound

\begin{tabular}{lcl}
\hline Multiply & By & To obtain \\
\hline kilometer $(\mathrm{km})$ & Length & \\
\hline & 0.6214 & mile $(\mathrm{mi})$ \\
\hline square kilometer $\left(\mathrm{km}^{2}\right)$ & Area & \\
\hline & 0.3861 & square mile $\left(\mathrm{mi}^{2}\right)$ \\
\hline cubic meter per second $\left(\mathrm{m}^{3} / \mathrm{s}\right)$ & Flow rate & \\
cubic meter per second $\left(\mathrm{m}^{3} / \mathrm{s}\right)$ & 70.07 & acre-foot per day $(\mathrm{acre}-\mathrm{ft} / \mathrm{d})$ \\
liter per second $(\mathrm{L} / \mathrm{s})$ & 35.31 & cubic foot per second $(\mathrm{ft} / \mathrm{s})$ \\
\hline
\end{tabular}

Temperature in degrees Celsius $\left({ }^{\circ} \mathrm{C}\right)$ may be converted to degrees Fahrenheit $\left({ }^{\circ} \mathrm{F}\right)$ as follows:

$$
{ }^{\circ} \mathrm{F}=\left(1.8 \times{ }^{\circ} \mathrm{C}\right)+32
$$

Specific conductance is shown in microsiemens per centimeter at 25 degrees Celsius $(\mu \mathrm{S} / \mathrm{cm})$.

Concentrations of chemical constituents in water are shown in either milligrams per liter ( $\mathrm{mg} / \mathrm{L}$ ) or micrograms per liter $(\mu \mathrm{g} / \mathrm{L})$.

\section{Horizontal Datum}

Horizontal coordinate information is referenced to the North American Datum of 1983 (NAD 83). 
Blank Page 


\title{
Compilation of Historical Water-Quality Data for Selected Springs in Texas, by Ecoregion
}

\author{
By Franklin T. Heitmuller and Iona P. Williams
}

\section{Abstract}

Springs are important hydrologic features in Texas. A database of about 2,000 historically documented springs and available spring-flow measurements previously has been compiled and published, but water-quality data remain scattered in published sources. This report by the U.S. Geological Survey, in cooperation with the Texas Parks and Wildlife Department, documents the compilation of data for 232 springs in Texas on the basis of a set of criteria and the development of a waterquality database for the selected springs. The selection of springs for compilation of historical water-quality data in Texas was made using existing digital and hard-copy data, responses to mailed surveys, selection criteria established by various stakeholders, geographic information systems, and digital database queries. Most springs were selected by computing the highest mean spring flows for each Texas level III ecoregion. A brief assessment of the water-quality data for springs in Texas shows that few data are available in the Arizona/New Mexico Mountains, High Plains, East Central Texas Plains, Western Gulf Coastal Plain, and South Central Plains ecoregions. Waterquality data are more abundant for the Chihuahuan Deserts, Edwards Plateau, and Texas Blackland Prairies ecoregions. Selected constituent concentrations in Texas springs, including silica, calcium, magnesium, sodium, potassium, strontium, sulfate, chloride, fluoride, nitrate (nitrogen), dissolved solids, and hardness (as calcium carbonate) are comparatively high in the Chihuahuan Deserts, Southwestern Tablelands, Central Great Plains, and Cross Timbers ecoregions, mostly as a result of subsurface geology. Comparatively low concentrations of selected constituents in Texas springs are associated with the Arizona/New Mexico Mountains, Southern Texas Plains, East Central Texas Plains, and South Central Plains ecoregions.

\section{Introduction}

Springs and seeps are natural features in the bedrock or soil that function as discrete or clustered outlets to convey ground water to the surface. Ground water discharges through one orifice, multiple orifices, or seeps in the rock or soil. Springs commonly occur on hill slopes or valleys where a permeable rock unit overlies relatively impermeable strata, or along faults where a permeable rock unit is offset and abuts an impermeable unit. Other springs are the result of emergent alluvial underflow, karst features, or geothermal activity. Some areas are characterized by a high spatial density of springs; these include karstic environments, faults expressed at the land surface, valleys, and escarpments. Springs commonly form the head of a stream valley, a knickpoint of upstream valley incision, or a vertical step in streambed elevation.

Spring flow commonly is a substantial or even primary contributor to the base flow of rivers and streams. In particular, during drought conditions, springs account for almost the entire flow along some river reaches. Springs often flow at a constant rate if sourced by a relatively large ground-water recharge area or by an aquifer of low transmissivity (Brune, 1981). Fluctuations in spring flow can be attributed to either climatic conditions or ground-water withdrawals, and flow variation is exaggerated for springs with small recharge areas of high transmissivity (Brune, 1981). Water-quality data for spring flow can be used to determine flow paths and rock units that were in contact with the ground water (Cartwright and others, 2002; Grasby and others, 2000). For example, a dissolved solids concentration of 1,000 milligrams per liter or more might indicate long residence times or sulfur or halite deposits beneath the surface. The temperature of spring water can indicate the depth of the water source (Brune, 1981), such that springs near the mean annual surface temperature have shallow flow paths relative to springs warmer than mean annual surface temperature.

The importance of springs in identifying the sites of human habitation is evident from prehistoric artifacts that have been found at numerous springs across Texas (Brune, 1981; Shiner, 1983). Sites near springs were originally selected to provide a water supply for many cities in Texas, including Austin, Big Spring, Brackettville, Del Rio, Dickens, Fort Stockton, Jacksboro, Lampasas, New Braunfels, Salado, San Antonio, San Marcos, Uvalde, and Waco. Historical forts in Texas located 


\section{Compilation of Historical Water-Quality Data for Selected Springs in Texas, by Ecoregion}

near springs include Fort Clark, Fort McKavett, Fort Richardson, and Fort Stockton.

Springs also serve as habitat for numerous species (Hubbs, 2001). Many springs in Texas are habitat for endangered or threatened species or both: for example the Barton Springs salamander (Eurycea sosorum), Texas wild rice (Zizania texana) downstream of San Marcos Springs in San Marcos, and the fountain darter (Etheostoma fonticola) in Comal Springs in New Braunfels. In West Texas, the Comanche Springs pupfish (Cyprinodon elegans) resides in San Solomon Spring; Comanche Springs generally has been dry since 1962 (Brannan and others, 2003).

In Texas, springs are a highly visible component of the hydrologic cycle. Federal and State agencies, resource conservation groups, water managers, municipalities, landowners, and even people who use springs or spring-fed rivers for recreation give close attention to the quantity and quality of water discharging from springs. From the perspective of many individuals and entities, springs serve as an indicator of the quality and availability of ground water (Bonacci, 1995).

In 2003, the U.S. Geological Survey (USGS), in cooperation with the Texas Water Development Board (TWDB), published a database of Texas springs and spring-flow measurements (Heitmuller and Reece, 2003). Data sources for this database were limited, however, to digital spreadsheets from the TWDB and Capitol Environmental Services, the USGS National Water Information System (NWIS), and hard-copy annual Water-Data Reports and Water-Supply Papers of the USGS. Heitmuller and Reece (2003) represents only springs with verified geographic coordinates in Texas; the authors of that publication acknowledge the existence of many springs not included in the database.

Following the publication of Heitmuller and Reece (2003), a series of meetings were held at the USGS office in Austin, Texas, between December 2003 and March 2004 to organize further investigative efforts related to springs in Texas. Participants in the meetings represented the interests of Federal and State agencies, nonprofit organizations, universities, research centers, and private landowners. One outcome of the meetings was a project by the USGS, in cooperation with the Texas Parks and Wildlife Department, to select primary springs in Texas and compile existing water-quantity and water-quality data for those springs into a database. The database then would serve as a platform for future water-quality and spring-flow monitoring. The selection of springs would be based on criteria that include spring flow, historical and cultural importance, water use, habitat to unique species, and linkage to aquifers or streamflow. An important consideration in the scope of the work was to ensure an adequate regional representation of springs.

\section{Purpose and Scope}

The purpose of this report is to document the compilation of a water-quality database for selected primary springs throughout Texas. The report also documents the sources and procedures used to select springs for the water-quality database and provides maps of selected constituents and explanations of spring water quality for level III Texas ecoregions. Level III ecoregions are land areas identified by the U.S. Environmental Protection Agency (2004) with similar geology, physiography, vegetation, climate, soils, land use, and hydrology (Griffith and others, 2004).

\section{Review of Existing Data}

Before 1894, no systematic data collection was done on springs in Texas, although a few discrete pre-1894 spring-flow estimates are available. The first systematic data collection on a Texas spring was in 1894, when the USGS began to monitor the flow of Barton Springs in Austin. Spring-flow monitoring on other major Texas springs began soon thereafter, in 1895, at Comal Springs in New Braunfels, Las Moras Springs in Brackettville, and San Felipe Springs in Del Rio. The next documentation of springs and spring flow in Texas was done in the 1940s and 1950s by the Texas Board of Water Engineers (TBWE), now the TWDB. Records of wells and springs were published by county in TBWE ground-water resources reports (see Baker, 2005). These records contain spring names, owners, aquifer associations, and discrete spring-flow and water-quality measurements. The TWDB continued the compilation of spring records by county beginning in 1957. Additionally, a study of the geohydrology of Comal, San Marcos, and Hueco Springs (William F. Guyton \& Associates, 1979) was sponsored by the TWDB.

The most substantial springs and spring-flow documentation in Texas was done by Gunnar Brune in the 1970s. Brune (1975) presents site information, water quality, and spring-flow declines for 281 major and historical Texas springs. This report was a prelude to Brune (1981), a detailed compilation of all known springs in 183 counties in Texas. In addition to written accounts of visits to these springs, many spring-flow and waterquality measurements are provided. Currently (2006), a publication of springs for the remaining counties is not available.

\section{Acknowledgments}

The authors are grateful to Larry McKinney, Cindy Loeffler, Chad Norris, and David Bradsby of the Texas Parks and Wildlife Department for providing information and helpful suggestions during preparation of this report.

\section{Procedures for Data Compilation}

The selection of springs for compilation of historical water-quality data in Texas was made using existing digital and hard-copy data, responses to mailed surveys, selection criteria established by various stakeholders, geographic information systems (GIS), and various database queries. Field and laboratory work were not a component of this compilation; sources were limited to previously published data. 


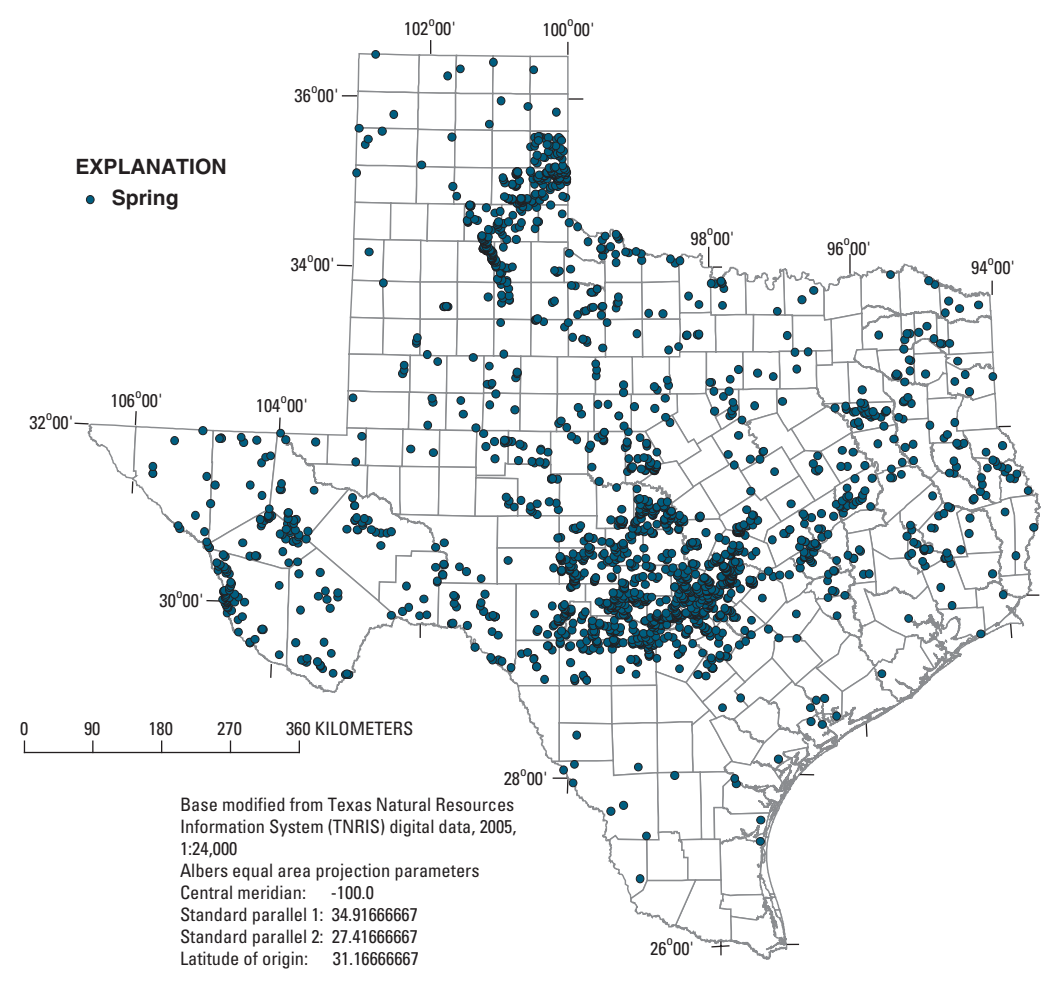

Figure 1. Locations of selected springs in Texas (from Heitmuller and Reece, 2003).

\section{Spring and Spring-Flow Database}

The primary data source for spring and spring-flow information is Heitmuller and Reece (2003), which contains geographic coordinates, spring names, site information, and known spring-flow measurements. Heitmuller and Reece (2003) contains 2,061 springs (fig. 1) and more than 7,300 spring-flow measurements, not including daily spring-flow values from USGS continuous-record gaging stations. Following the release of Heitmuller and Reece (2003), 1,895 spring-flow measurements from Brune $(1975,1981)$ were added to the database. The inclusion of these data into Heitmuller and Reece (2003) required an analysis and removal of duplicate flow measurements. The result was a comprehensive database of all known springs and spring-flow measurements in Texas. This comprehensive database of springs and spring-flow measurements is the source of the data used for analysis of spring flow for this report.

The comprehensive database of spring-flow measurements was used to compute mean spring flow of all springs. For the few springs that are continuously monitored, including Comal, San Marcos, and Barton Springs, the mean data published in volumes 1-5 of USGS "Water Resources Data, Texas, Water Year 2004" (Aragon Long and others, 2005) were used. For other springs that comprise multiple orifices, an effort was made to compute combined mean spring flow. Examples include Leona Springs in Uvalde County and Salado Springs in
Bell County, among others. This is consistent with methods used by the USGS and Brune $(1975,1981)$. No-flow measurements for the period of record also were used to compute mean spring flow.

\section{Springs Categorized by Ecoregions}

Springs in the comprehensive database were categorized into 12 level III ecoregions associated with Texas (table 1). As summarized by Griffith and others (2004), "Ecoregions denote areas of general similarity in ecosystems and in the type, quality, and quantity of environmental resources," and "ecological regions are hierarchical and can be identified through the analysis of the spatial patterns and the composition of biotic and abiotic phenomena that affect or reflect differences in ecosystem quality and integrity." Level III ecoregions in Texas were developed to serve as a spatial framework for assessment of ecosystems (U.S. Environmental Protection Agency, 2004). Areas within each Texas level III ecoregion have similar geology, physiography, vegetation, climate, soils, land use, wildlife, and hydrology (Griffith and others, 2004). Level III ecoregions were chosen as a regional framework for assessment of Texas springs because (1) the entire State is represented, (2) all springs can be associated with an ecoregion, and (3) the differences in geology, physiography, hydrology, and other factors between ecoregions should be reflected in the water quality of springs. The number of level III ecoregions in Texas, therefore, reflects 


\section{Compilation of Historical Water-Quality Data for Selected Springs in Texas, by Ecoregion}

Table 1. Number and percentage of total springs in database for Texas level III ecoregions (Heitmuller and Reece, 2003).

[ $\mathrm{km}^{2}$, square kilometers]

\begin{tabular}{clccc}
\hline Ecoregion ID & \multicolumn{1}{c}{ Ecoregion name } & $\begin{array}{c}\text { Ecoregion area } \\
\left(\mathrm{km}^{2}\right)\end{array}$ & $\begin{array}{c}\text { Number of springs } \\
\text { in database }\end{array}$ & $\begin{array}{c}\text { Percentage of all } \\
\text { springs in database }\end{array}$ \\
\hline 23 & Arizona/New Mexico Mountains & 219 & 3 & 0.15 \\
24 & Chihuahuan Desert & 91,362 & 206 & 10.0 \\
25 & High Plains & 84,063 & 43 & 2.09 \\
26 & Southwestern Tablelands & 60,185 & 304 & 14.8 \\
27 & Central Great Plains & 46,693 & 135 & 6.55 \\
29 & Cross Timbers & 51,920 & 129 & 6.26 \\
30 & Edwards Plateau & 74,963 & 818 & 39.7 \\
31 & Southern Texas Plains & 53,492 & 36 & 1.75 \\
32 & Texas Blackland Prairies & 43,381 & 107 & 5.19 \\
33 & East Central Texas Plains & 54,809 & 149 & 7.23 \\
34 & Western Gulf Coastal Plain & 59,787 & 16 & .78 \\
35 & South Central Plains & 63,977 & 115 & 5.58 \\
& TOTALS FOR TEXAS & $\mathbf{6 8 4 , 8 5 1}$ & $\mathbf{2 , 0 6 1}$ & $\mathbf{1 0 0}$ \\
\hline
\end{tabular}

the desired diversity and level of regional assessment. Aquifers were not used to categorize springs because not all springs emerge from a State-of-Texas-designated aquifer. River basins were not used to categorize springs because river basins can extend across a number of ecoregions.

A limitation of the ecoregion categorization is that some springs with relatively long flow paths or large recharge areas emerge in a different ecoregion than the ecoregion contributing the water. For example, this limitation is particularly evident along relatively sharp ecoregion boundaries, including the Caprock escarpment between Ecoregions 25 and 26 and the Balcones escarpment between Ecoregions 30, 31, and 32. The water quality of large springs in Ecoregions 31 and 32, including Comal, San Marcos, Barton, San Antonio, San Felipe, and Las Moras Springs, is correctly associated with the carbonate hydrogeology of Ecoregion 30 (Edwards Plateau). The water quality of numerous springs included in Ecoregion 26 is correctly associated with the Ogallala aquifer in Ecoregion 25 (High Plains). Additionally, the scale at which ecoregion boundaries are digitally represented is not sufficient to capture every detail of the actual landscape. For example, the boundary between Ecoregions 25 and 26 is straighter than the actual Caprock escarpment, effectively crossing the escarpment many times. As a result, some springs below the escarpment are assigned to Ecoregion 25 (High Plains), and others are assigned to Ecoregion 26 (Southwestern Tablelands). Regional waterquality assessments are presented for the digital ecoregions because of the ease that GIS provides in assigning springs. Furthermore, the region to which the spring contributes surface flow also is hydrologically connected to the spring.
Some ecoregions are relatively dry, flat, or not spatially extensive and do not have many springs; other ecoregions are relatively wet, sloped, or spatially extensive and have many springs. For example, Ecoregion 34 (Western Gulf Coastal Plain) is relatively flat and is represented by only 16 springs in the database. However, the highly conductive (to flow) hydrology and relatively steep topography of Ecoregion 30 (Edwards Plateau) is represented by 818 springs in the comprehensive database. The number of springs for each ecoregion was divided by the total number of springs in the database to determine the percentage of springs in each ecoregion (table 1).

Following categorization of springs into level III ecoregions, the largest springs within each ecoregion (table 2) were ranked by mean spring flow. The 10 largest springs in Texas are listed in table 3 . The order generally agrees with the ranking of Brune (1981). The lower ranking of Comanche Springs reflects a number of no-flow measurements made since 1981 . The rankings in tables 2 and 3 are somewhat tenuous, however, as mean spring flow was computed from available measurements. Comal, Barton, and San Marcos Springs have continuous flow data, some springs have hundreds of discrete measurements, and other springs have very few discrete measurements over short periods of record.

\section{Spring Survey for Selected Stakeholders in Texas}

The selection of springs for historical water-quality and spring-flow data entry and analysis for this report was facilitated by a survey (fig. 2) mailed to stakeholders across Texas. More than 400 surveys were sent to numerous Federal and State agencies, water districts, nonprofit organizations, and other 
Table 2. Largest springs in each Texas level III ecoregion on basis of mean spring flow for entire period of record.

[Mean spring flow computed mostly from discrete measurements, but some time-averaged values used to extend period of record. $\mathrm{m}^{3} / \mathrm{s}$, cubic meters per second]

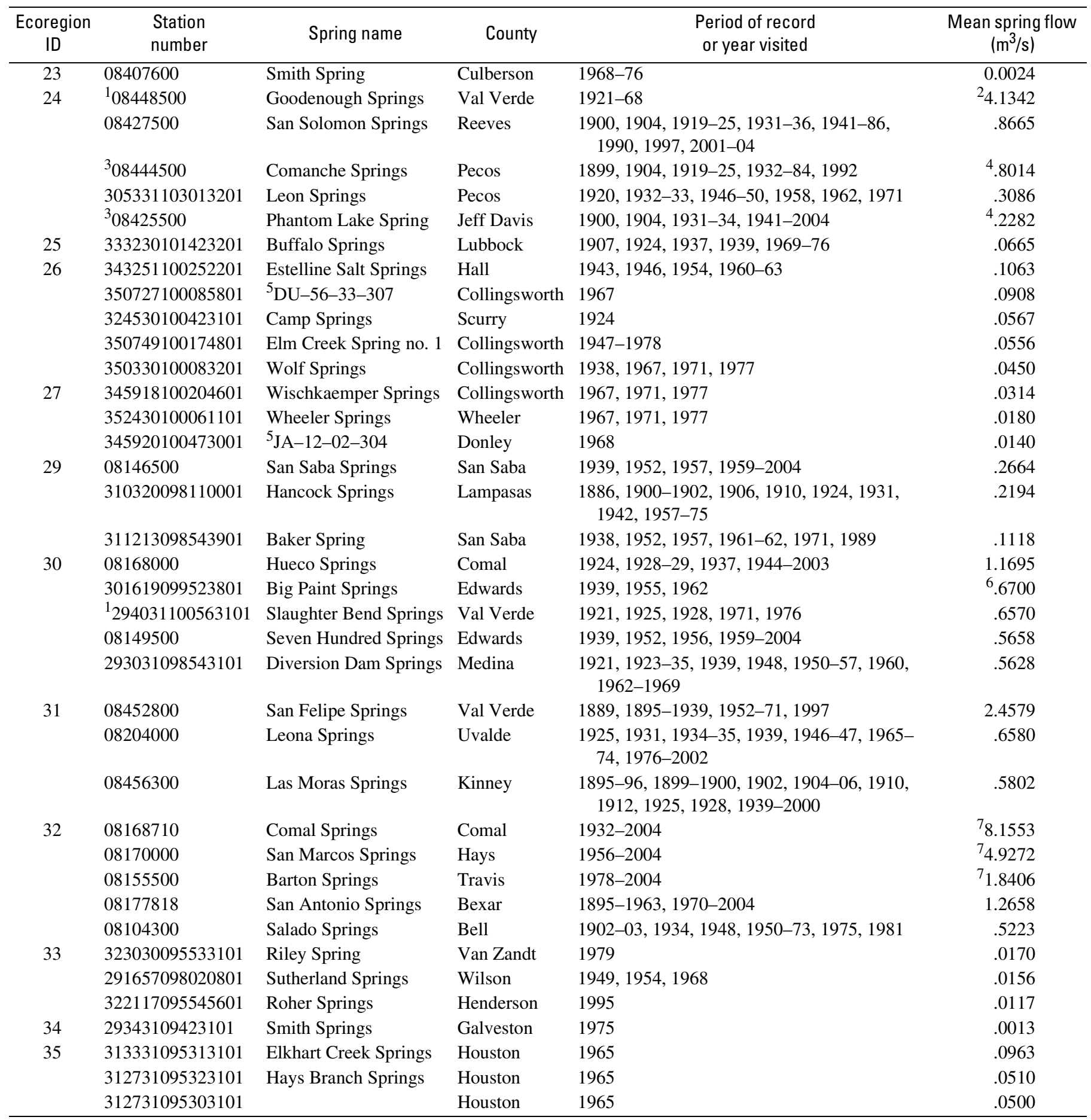

\footnotetext{
${ }^{1}$ Currently beneath surface of Lake Amistad.

${ }^{2}$ Computed from monthly mean spring flow for period of record.

${ }^{3}$ Now generally dry.

${ }^{4}$ Includes numerous no-flow measurements.

${ }^{5}$ Name derived from Texas State well number.

${ }^{6}$ Based only on three measurements.

${ }^{7}$ Computed from continuous daily spring flow.
} 


\section{Compilation of Historical Water-Quality Data for Selected Springs in Texas, by Ecoregion}

Table 3. Largest springs in Texas on basis of mean spring flow for entire period of record.

[Mean spring flow computed mostly from discrete measurements, but some time-averaged values used to extend period of record. $\mathrm{m}^{3} / \mathrm{s}$, cubic meters per second]

\begin{tabular}{|c|c|c|c|c|c|}
\hline $\begin{array}{l}\text { Station } \\
\text { number }\end{array}$ & Spring name & County & $\begin{array}{l}\text { Level III } \\
\text { ecoregion ID }\end{array}$ & $\begin{array}{l}\text { Period of record } \\
\text { or year visited }\end{array}$ & $\begin{array}{l}\text { Mean spring flow } \\
\left(\mathrm{m}^{3} / \mathrm{s}\right)\end{array}$ \\
\hline 08168710 & Comal Springs & Comal & 32 & $1932-2004$ & ${ }^{1} 8.1553$ \\
\hline 08170000 & San Marcos Springs & Hays & 32 & 1956-2004 & ${ }^{1} 4.9272$ \\
\hline${ }^{2} 08448500$ & Goodenough Springs & Val Verde & 24 & $1921-68$ & ${ }^{3} 4.1342$ \\
\hline 08155500 & Barton Springs & Travis & 32 & $1978-2004$ & ${ }^{1} 1.8406$ \\
\hline 08177818 & San Antonio Springs & Bexar & 32 & 1895-1963, 1970-2004 & 1.2658 \\
\hline 08168000 & Hueco Springs & Comal & 30 & $1924,1928-29,1937,1944-2003$ & 1.1695 \\
\hline 08427500 & San Solomon Springs & Reeves & 24 & $\begin{array}{l}1900,1904,1919-25,1931-36 \\
1941-86,1990,1997,2001-04\end{array}$ & .8665 \\
\hline 301619099523801 & Big Paint Springs & Edwards & 30 & $1939,1955,1962$ & ${ }^{6} .6700$ \\
\hline
\end{tabular}

${ }^{1}$ Computed from continuous daily spring flow.

${ }^{2}$ Currently beneath surface of Lake Amistad.

${ }^{3}$ Computed from monthly mean spring flow for period of record.

${ }^{4}$ Now generally dry.

${ }^{5}$ Includes numerous no-flow measurements.

${ }^{6}$ Based on only three measurements.

water-resource entities in Texas. Emphasis was on surveying local recipients; most surveys were mailed to the distributed offices of larger agencies. Recipients included the Texas Parks and Wildlife Department, the Texas Commission on Environmental Quality, the Texas Water Development Board, the Texas Historical Commission, the Texas Department of Agriculture, regional water planning groups, ground-water conservation districts, river authorities, selected university faculty, numerous nonprofit organizations, and private individuals. Surveys were also sent to Federal agencies with a presence in Texas, including the USGS (Water Science Centers), U.S. Fish and Wildlife Service, and U.S. Department of Agriculture, Natural Resources Conservation Service.

The survey was designed for a flexible response and encouraged recipients to provide information on springs important to their jurisdiction or within their expertise. Relative importance could be attributed to large or persistent spring flow; historical or cultural significance; habitat for endangered, threatened, or other species of concern; water use; contribution to surface water; aquifer association; or other unique environmental characteristics. All survey responses were reviewed and tabulated; of 416 surveys mailed out, 54 responses were made through mail, e-mail, or phone. Of these, 34 reported no known springs or did not provide any specific springs in their response. However, the small number of responses, both with and without information on specific springs, represented a considerable variety of stakeholders across most of Texas. Fifty-eight springs were reported to match one or more elements of the criteria described above.

\section{Application of Criteria to Selected Springs for Water- Quality Database}

Springs primarily were selected for the water-quality database of this report by (1) mean spring-flow ranking and (2) spring-survey response. Springs with the highest mean spring flow were selected for each ecoregion. To ensure that all level III ecoregions were adequately represented in the database, the number of springs selected for each ecoregion corresponded to the percentage of all Texas springs in that ecoregion (table 1). This percentage was applied to a goal of about 200 springs for the entire State; the goal of about 200 springs 
Name:

Organization:

Location:

Telephone:

E-mail:

Check all that apply. Please provide specific details under 'Justification', including name of species, aquifer name, use of water, and so forth, to the extent you are able.

Spring:

County:

Importance:

Regionally large spring flow __ Currently Historically

Historically / culturally significant

Habitat for endangered, threatened, or species of concern

Water-use $\square$ Source of water to large river basins

Importance to an aquifer

$\square$ Unique environmental characteristics $\square$ Other

Justification:

Figure 2. Excerpt of survey mailed to numerous stakeholders across Texas.

was established during stakeholder meetings between December 2003 and March 2004. For example, Ecoregion 24 (Chihuahuan Desert) contains 206 springs, or about 10 percent of all springs in the database. To ensure adequate representation in the water-quality database, about 10 percent of springs in Ecoregion 24 were selected, or 20 springs. Ecoregion 23 (Arizona/New Mexico Mountains) was the only ecoregion that did not contain at least 1 percent of all Texas springs. Nonetheless, the largest spring in this ecoregion was selected. This method resulted in the selection of 209 springs.

Following the quantitative method of selecting springs on the basis of mean spring flow, qualitative methods were used to select additional springs. Eleven springs were selected on the basis of only the responses to mailed surveys, especially if the springs were mentioned in Brune (1975). Additionally, four springs that were not selected, but that the authors felt were important on the basis of history or recreational use, were added to the water-quality database. These included Hamilton Springs in Travis County, Krause Springs in Burnet County, Chinati Hot Springs in Presidio County, and Carrizo Springs in Dimmit County, among others.

Finally, for some large areas of the State not represented by the selected springs, the spring-flow database (Heitmuller and Reece, 2003) and spring-flow measurements from Brune $(1975,1981)$ were assessed to select the largest springs in those areas. Eight springs were selected by this method. For example, 


\section{Compilation of Historical Water-Quality Data for Selected Springs in Texas, by Ecoregion}

in north-central Texas a large area that includes parts of Ecoregions 27, 29, and 32 was not represented by any springs. For this area, four springs with the largest mean spring flow were chosen, including Buffalo Springs in Clay County, Browder Springs in Dallas County, PX-32-52-503 in Johnson County, and Pierson Spring in Bosque County.

A total of 232 springs were selected for inclusion in the water-quality database of this report (fig. 3; table 4, at end of report) using both quantitative and qualitative methods, including mean spring flow, responses to mailed surveys, Brune (1975), and judgment by the authors based on geographic coverage and other criteria. Most springs were chosen by an assessment of mean spring flow for each ecoregion. The springs represent all level III ecoregions in Texas, eight of nine major aquifers (fig. 4), 11 of 21 minor aquifers (fig. 5), and 16 of 23 river basins in the State (fig. 6). Major and minor aquifers are those designated as such by the TWDB (Ashworth and Hopkins, 1995).

\section{Spring Water-Quality Database}

All selected springs and associated spring-flow measurements were entered into a new database. A table was created in this database to store water-quality data, including concentrations of selected constituents, specific conductance, $\mathrm{pH}$, and temperature (fig. 7). Water-quality data were obtained from (1) TBWE hard-copy bulletins, (2) TWDB hard-copy reports, (3) Brune $(1975,1981),(4)$ the TWDB well information database (Texas Water Development Board, 2005), and (5) the USGS NWIS digital database (U.S. Geological Survey, 2001). TBWE bulletins are organized by county or river basin and contain data on wells and springs; most were published in the 1950s and early 1960s. TWDB reports are similar to TBWE bulletins and have been published from 1965 to the present (2006). Brune $(1975,1981)$ contains water-quality data for a number of springs. Measurements from the TWDB well information database were queried for the selected springs. The NWIS database serves as the storage for all hydrologic data of the USGS. All water-quality measurements were manually entered except those from the TWDB water-quality database and NWIS, which were digitally imported. Duplicate measurements in two or more sources were removed.

The temporal range in water-quality data for springs in Texas spans from the late 19th century to the present (2006). Sampling and laboratory techniques have changed considerably since the earliest samples and measurements were obtained, resulting in greater accuracy and precision of data in more recent years. Additionally, numerous water-quality measurements from the late 19th and early 20th centuries do not have quality-assurance or quality-control data available. Of more than 51,000 individual water-quality values in the database, about 11,500 measurements do not have quality-assurance codes. The water-quality assessments provided for each level III ecoregion in Texas include all available measurements, as temporal extension of the data was desired. For ecoregions with few data, some bias might be introduced through earlier water- quality samples obtained and measured with different technology. Seasonal bias also might be inherent because spring flow and associated concentrations of selected constituents vary with seasonal changes in precipitation and aquifer capacity. Database queries show that water quality of Texas springs has been sampled fairly consistently for each of the four seasons, even for ecoregions with few data.

\section{Historical Water-Quality Data for Selected Springs, by Ecoregion}

A total of 11,675 individual values for various waterquality constituents and properties (table 5, at end of report) were used to compute statistical summaries of water-quality data for selected springs in Texas. More than 50,000 individual values are provided in the database, the difference representing additional water-quality constituents, such as ammonia, cadmium, and many organic compounds that are not presented in this report. Water-quality constituents and properties used in the analyses and presented on maps are listed in table 6 (at end of report). A map of the spatial distribution of water-quality values for springs in each Texas ecoregion is shown in figure 8. Ecoregion 32 (Texas Blackland Prairies) has the highest number of values $(5,387)$ because some of the largest and most frequently monitored springs in Texas issue from that ecoregion, including Comal, San Marcos, Barton, and San Antonio Springs. Ecoregion 23 (Arizona/New Mexico Mountains) has only 13 waterquality values because of its small size and associated representation in the database.

A brief assessment of the water-quality data is presented for each level III ecoregion in Texas. The mean, median, and standard deviation of water-quality constituents and properties for selected springs in Texas, by ecoregion, are listed in table 7 (at end of report). Censored data, or data reported as less than a reporting level, were included as one-half the reporting level in the computation of summary statistics for each ecoregion. The minimum and maximum water-quality values, by ecoregion, are listed in table 8 (at end of report). Water-quality standards, mostly for drinking water, for selected constituents and properties are listed in table 9 (at end of report). Not all constituents and properties discussed in this report have water-quality standards. Maps showing the distribution of median water-quality values (table 7) are presented in figures 9-25. The authors recognize that some springs have considerably more water-quality data than others, which influences the summary statistics for each ecoregion. Of 1,474 visits for water-quality sampling entered in the database, five springs (Barton, Comal, Hueco, Old Mill, and San Marcos) account for 876 sampling visits. Barton Springs has the greatest number of sampling visits with 479. As a result, water-quality summary statistics for Ecoregion 32 (Texas Blackland Prairies) are greatly influenced. 


\section{EXPLANATION}

Level III Ecoregion ID and name

23-Arizona/New Mexico Mountains

24-Chihuahuan Deserts

25-High Plains

26-Southwestern Tablelands

27-Central Great Plains

$\square$ 29-Cross Timbers

30-Edwards Plateau

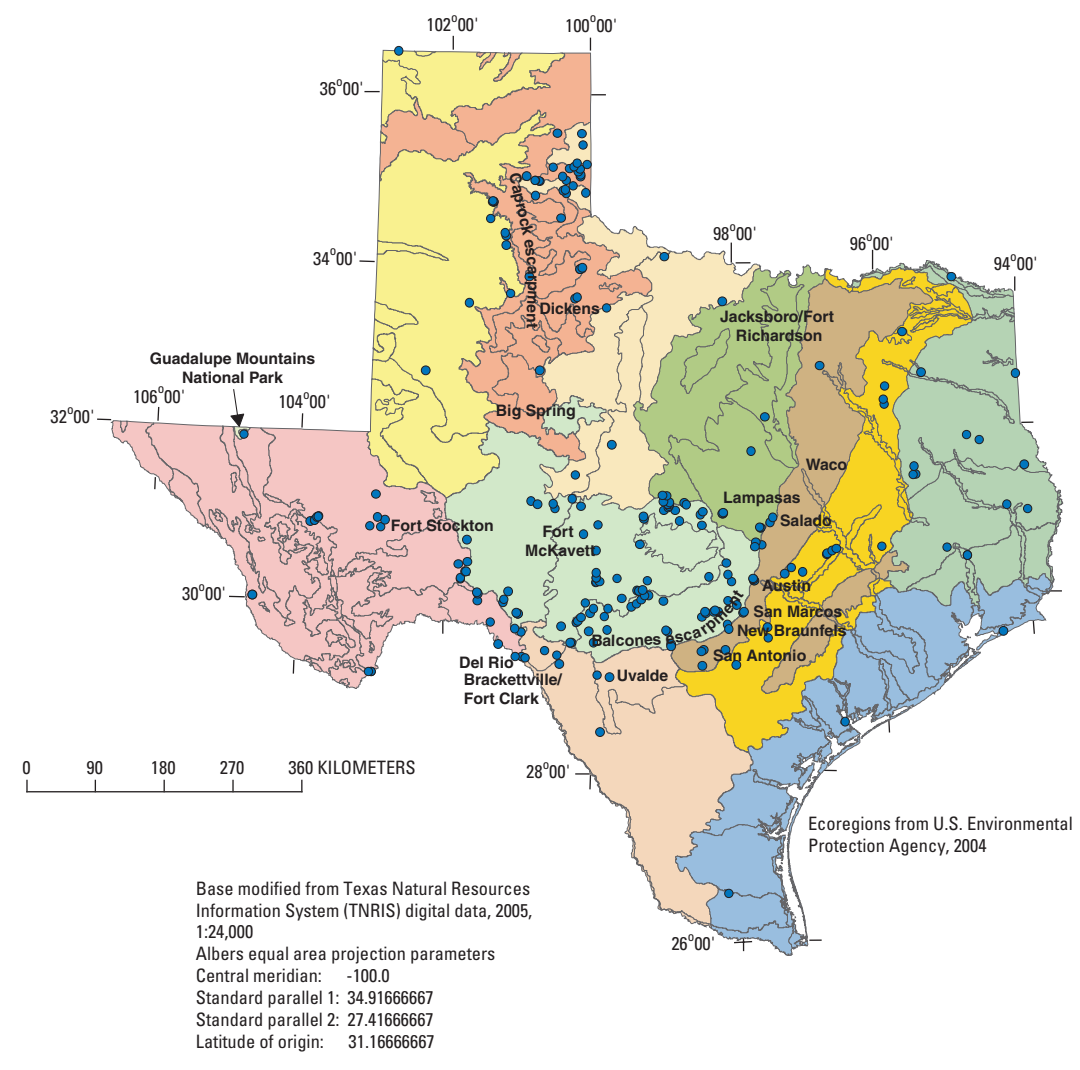

Figure 3. Springs selected for inclusion in the water-quality database of springs in Texas, by ecoregion.
EXPLANATION

Major aquifer

Cenozoic Pecos alluvium $\quad 2 / / \triangle$ Edwards-Trinity Plateau (downdip)

Seymour

Gulf Coast

Carrizo-Wilcox (outcrop)

Carrizo-Wilcox (downdip)

Hueco-Mesilla bolson

Ogallala

Edwards-Trinity Plateau (outcrop)
Edwards Balcones fault zone (outcrop)

VI/A Edwards Balcones fault zone (downdip)

Trinity (outcrop)

MIV Trinity (downdip)

- Spring
Outcrop is that part of a water-bearing rock layer that appears at the land surface. Downdip is that part of a water-beanhyoch

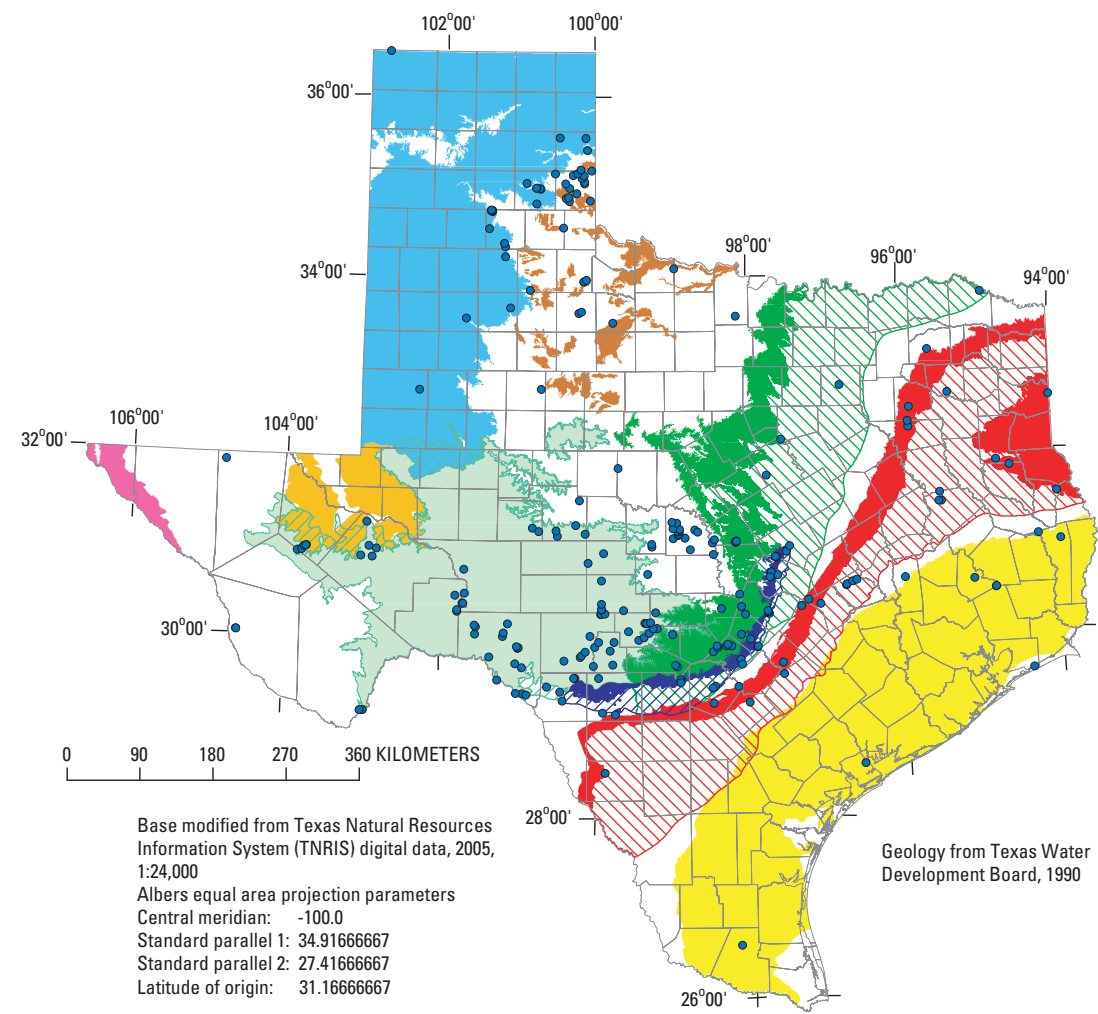

Figure 4. Major aquifers in Texas and springs selected for inclusion in the waterquality database of springs in Texas. 
EXPLANATION

$$
\text { Minor aquifer }
$$

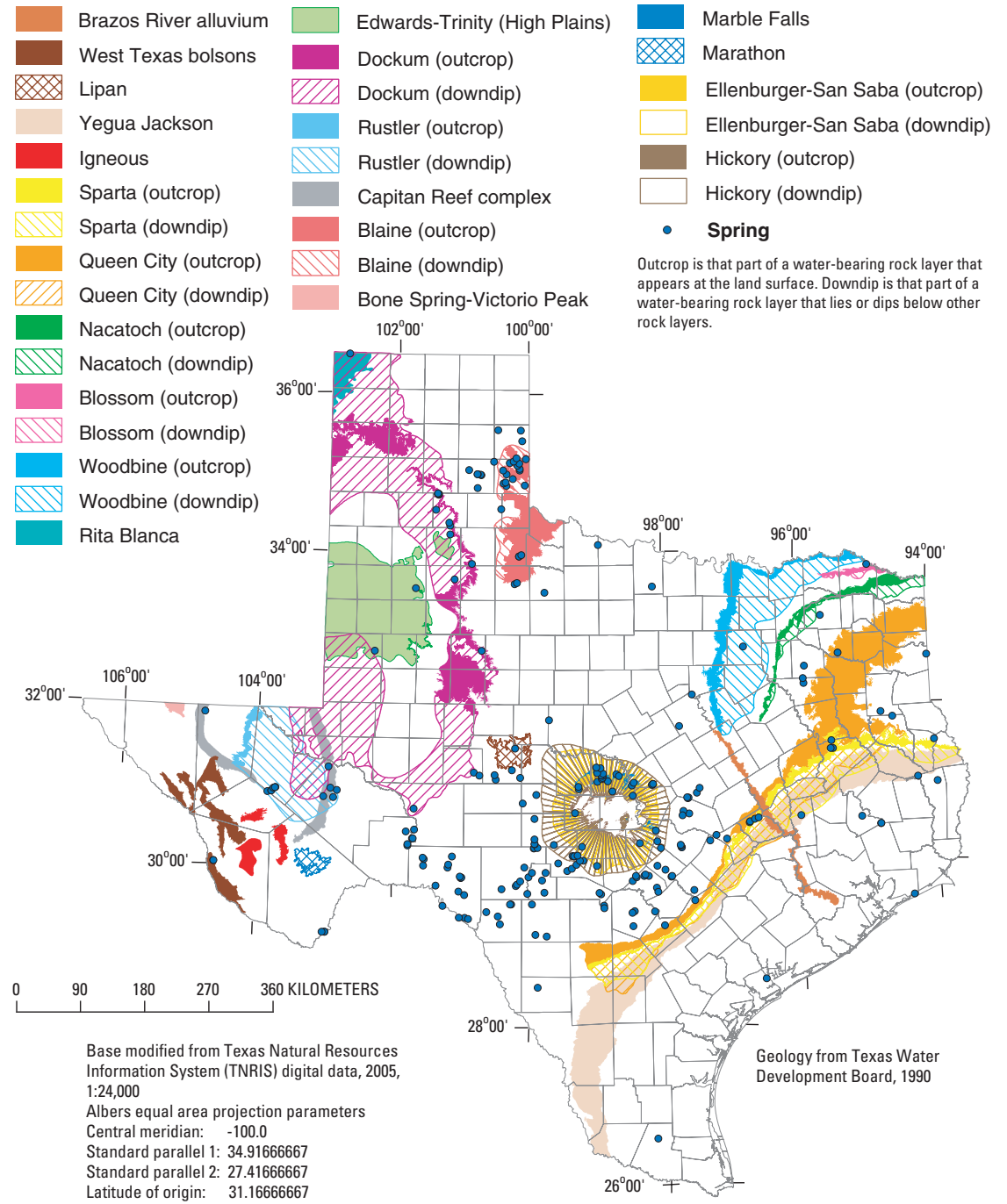

Figure 5. Minor aquifers in Texas and springs selected for inclusion in the waterquality database of springs in Texas.
EXPLANATION

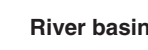

$\square$ Canadian

Red

Sulphur

Cypress

Sabine

Neches

Neches-Trinity

Trinity

Trinity-San Jacinto

San Jacinto $\quad{ }^{102^{\circ}} 0^{\circ} \quad 100^{\circ} 00^{\prime}$

$\square$ San Jacin

Brazos-Colorado

Colorado

Colorado-Lavaca

Lavaca

$\square$ Lavaca-Guadalupe

$\square$ Guadalupe

$\square$ San Antonio

$\square$ San Antonio-Nueces

$\square$ Nueces

$\square$ Nueces-Rio Grande

$\square$ Rio Grande

- Spring
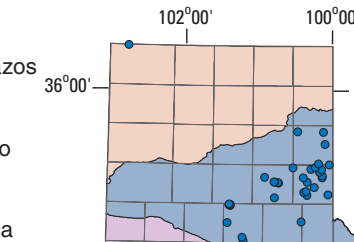

\section{然}

$34^{\circ} 00$

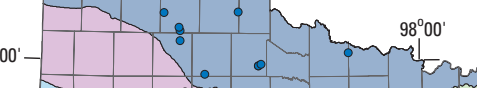

$96^{\circ} 00^{\prime}$ $94^{\circ} 00^{\prime}$

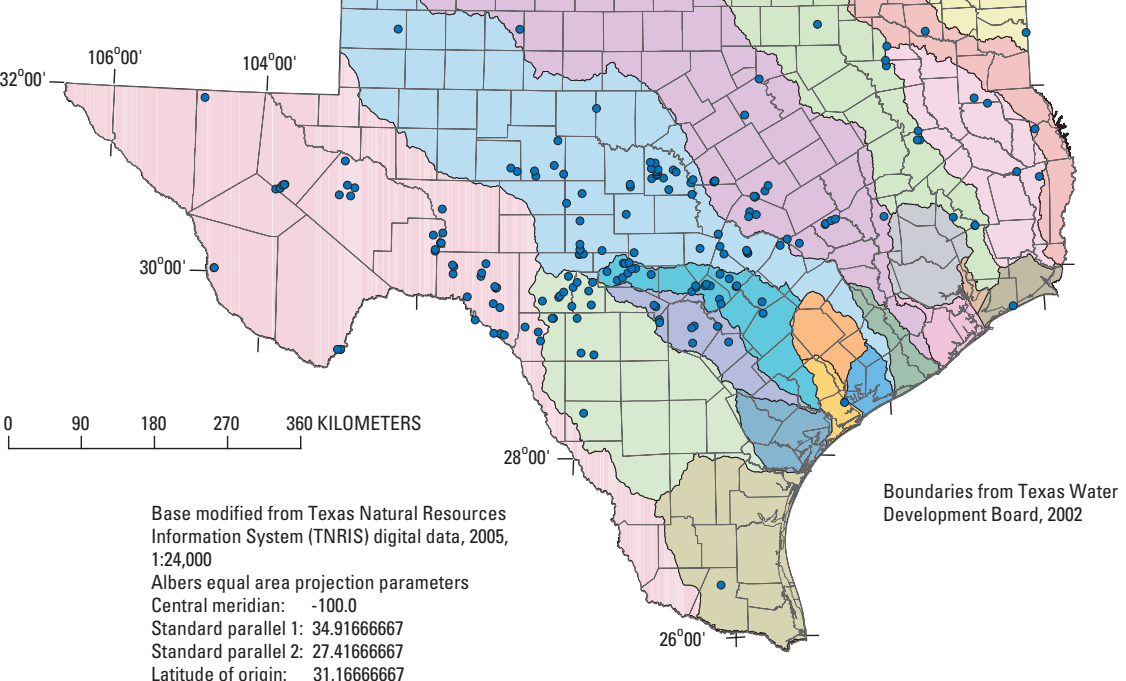

Figure 6. River basins in Texas and springs selected for inclusion in the water-quality database of springs in Texas. 


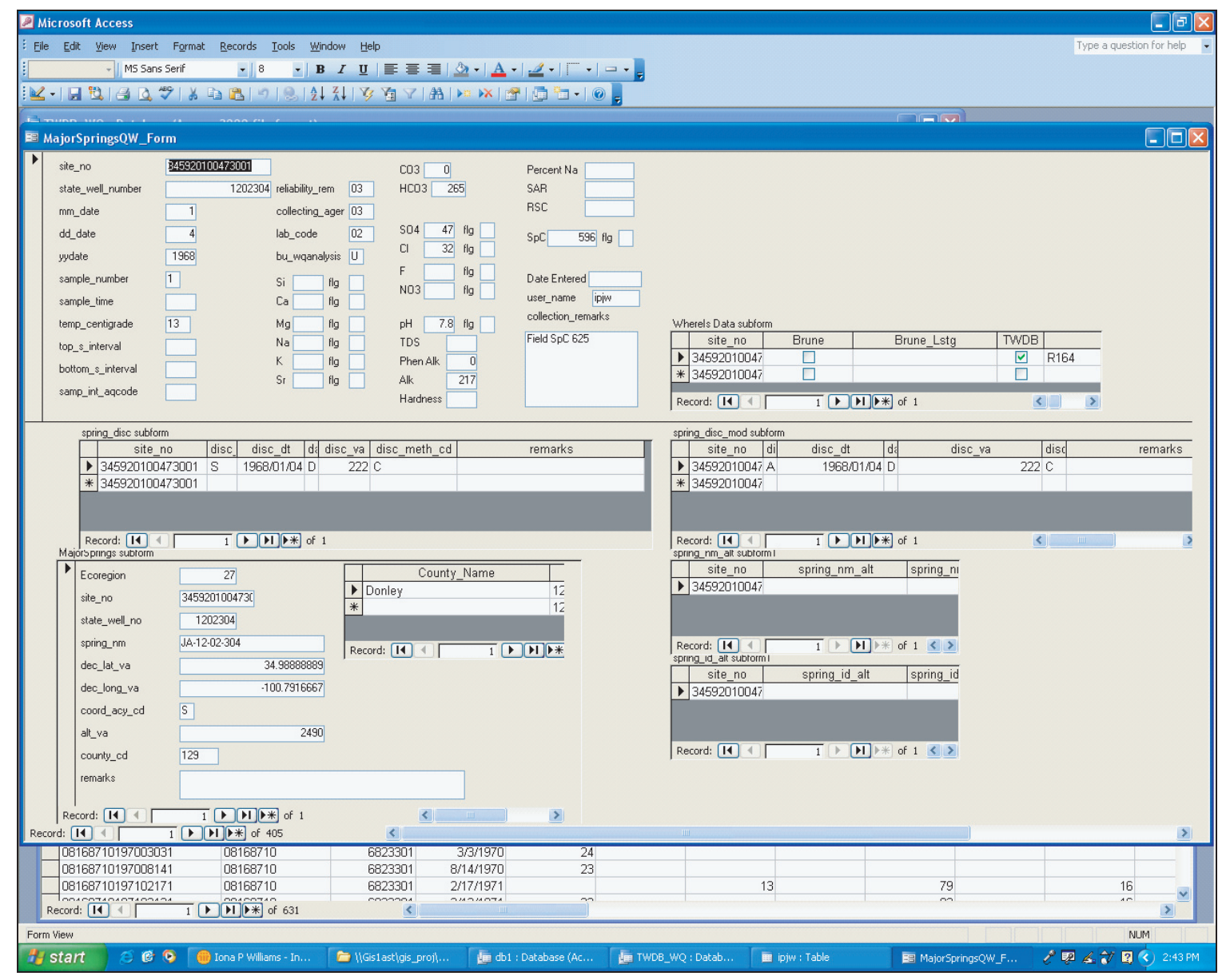

Figure 7. Screen capture of data-entry interface for water-quality database of springs in Texas.

\section{Arizona/New Mexico Mountains}

The Arizona/New Mexico Mountains (Ecoregion 23) is represented by one spring in the water-quality database, Smith Spring. The inclusion of only one spring is attributed to the very small area of the ecoregion (219 square kilometers) in Texas and the availability of only three springs in the database. Smith Spring in Guadalupe Mountains National Park issues from the Capitan Reef Complex aquifer, associated with a Permian carbonate reef platform (Ashworth and Hopkins, 1995) in the Guadalupe Mountains. Analysis of one sample from Smith Spring shows a dissolved solids concentration of 299 milligrams per liter, calcium concentration of 76 milligrams per liter, and bicarbonate concentration of 358 milligrams per liter. The concentrations of silica (10 milligrams per liter), sodium ( 2 milligrams per liter), and chloride ( 2 milligrams per liter) were lower than mean concentrations in selected springs of the other Texas level III ecoregions.

\section{Chihuahuan Deserts}

The Chihuahuan Deserts (Ecoregion 24) is represented by 29 springs in the water-quality database. A few of the selected springs in the Chihuahuan Deserts have comparatively long (Uliana and Sharp, 2001) or deep flow paths and spring waters characterized by high median concentrations of constituents and warm temperatures. Selected springs in the Chihuahuan Deserts have the highest median concentrations of calcium (177 milligrams per liter), magnesium (73 milligrams per liter), sodium (390 milligrams per liter), potassium (17 milligrams per liter), strontium (3.4 milligrams per liter), sulfate (383 milligrams per liter), chloride (246 milligrams per liter), fluoride (1.7 milligrams per liter), dissolved solids (1,343 milligrams per liter), and hardness as calcium carbonate (514 milligrams per liter) of all the level III ecoregions in Texas. Additionally, median specific conductance $(3,220$ microsiemens per centimeter at 25 degrees Celsius) and temperature ( 25 degrees Celsius) were the highest among springs of the level III ecoregions. 


\section{EXPLANATION}

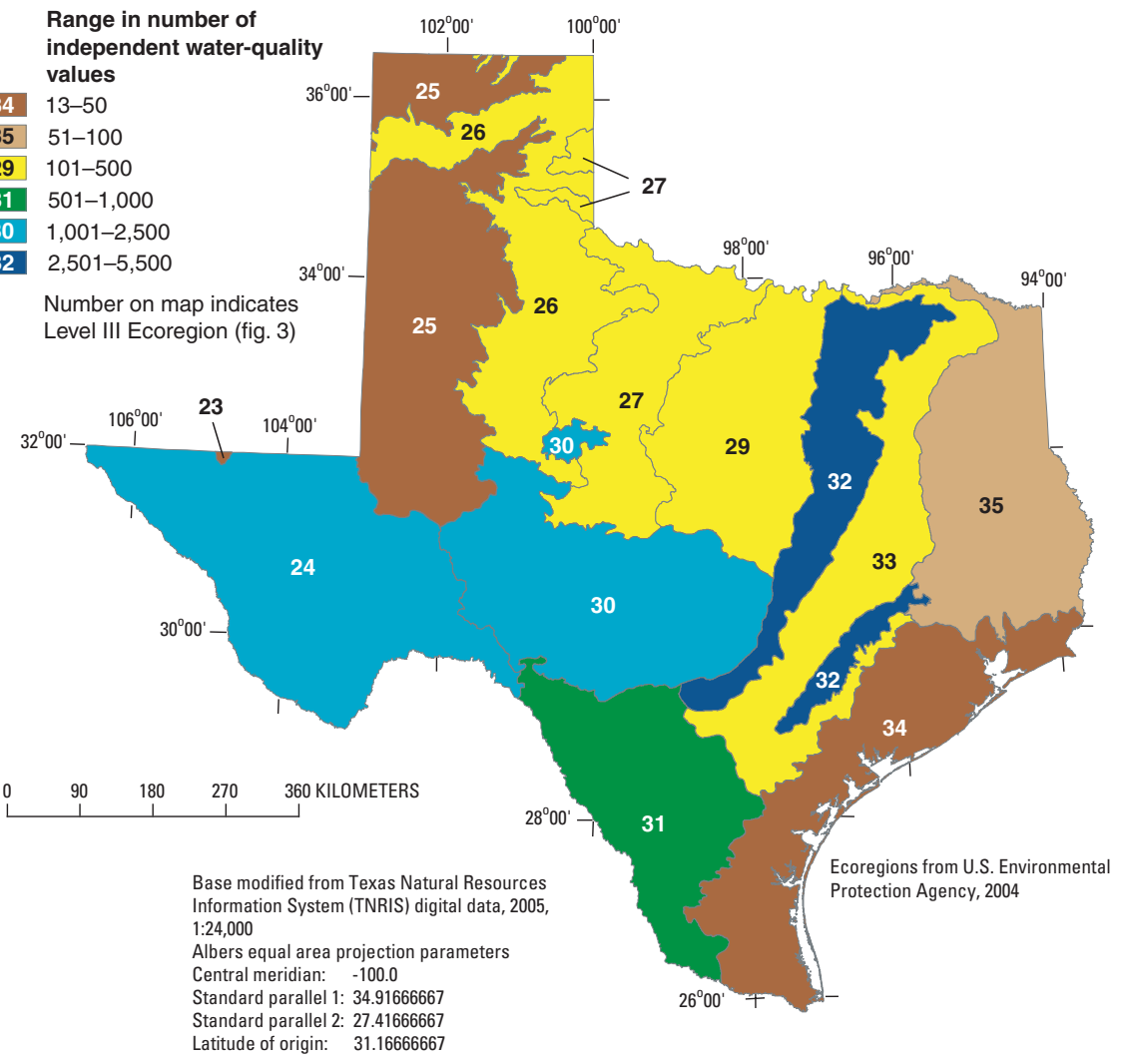

Figure 8. Spatial distribution of 11,675 water-quality values for selected springs in Texas, by ecoregion.

\section{EXPLANATION}

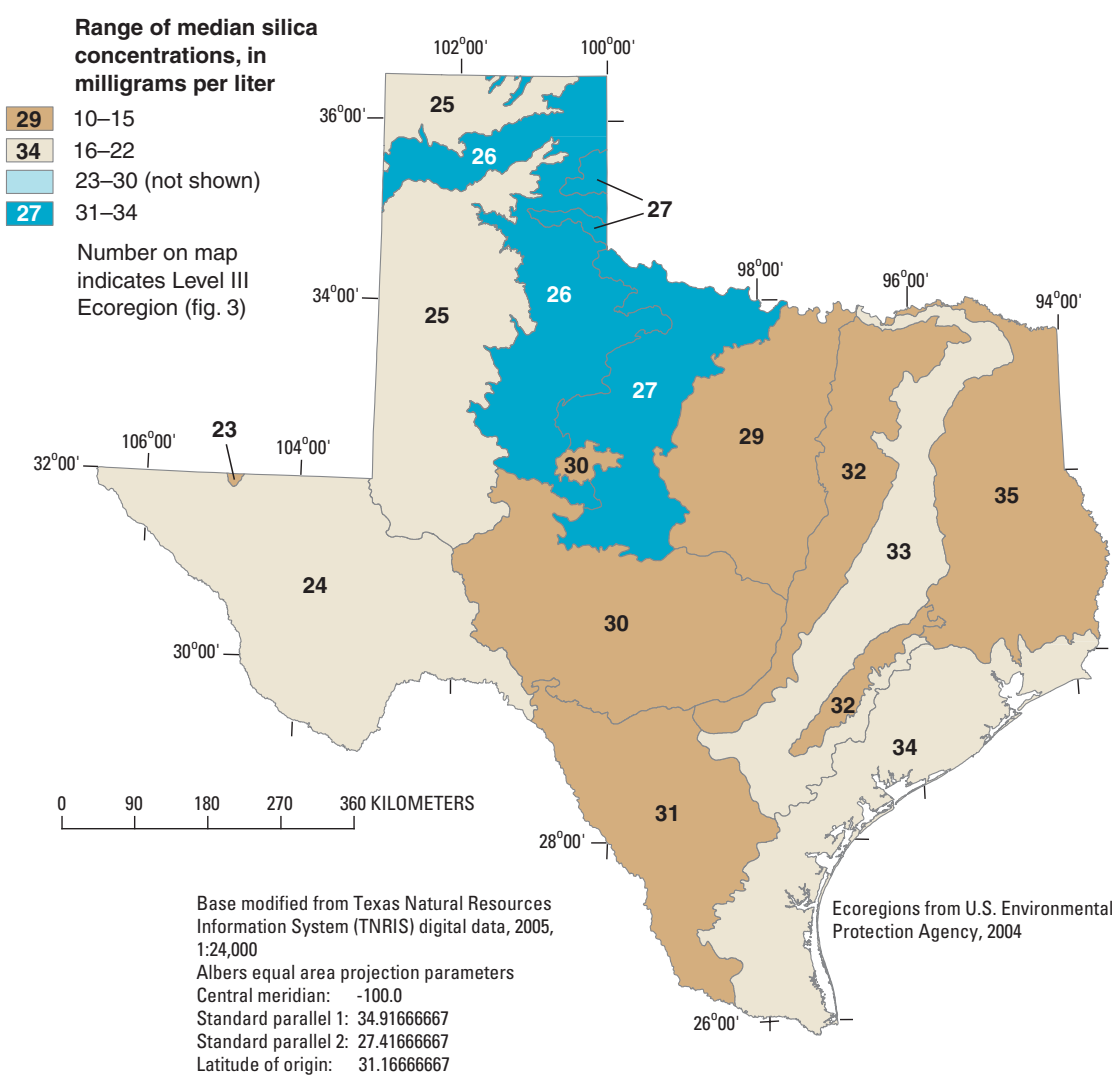

Figure 9. Range of median silica concentrations for selected springs in Texas, by ecoregion. 


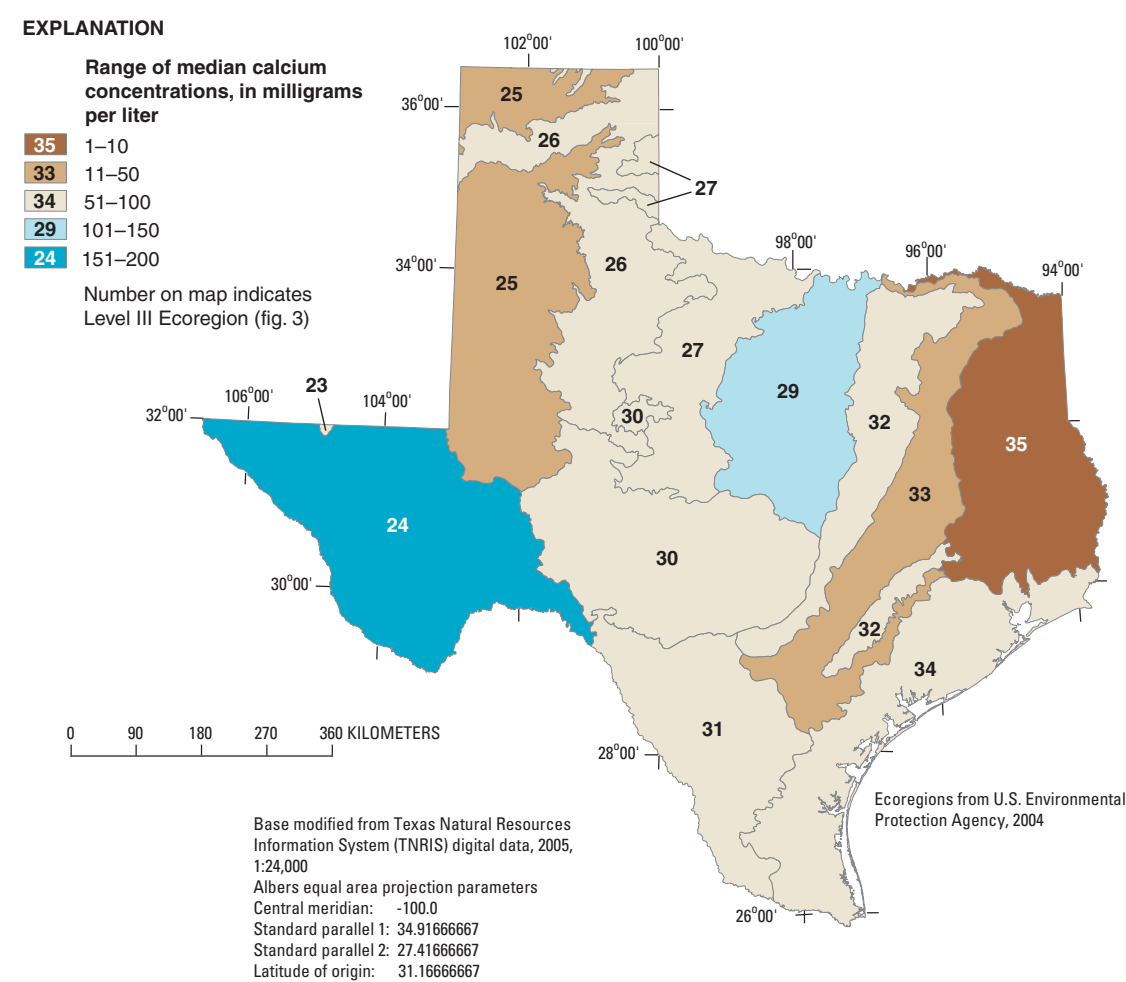

Figure 10. Range of median calcium concentrations for selected springs in Texas, by ecoregion.

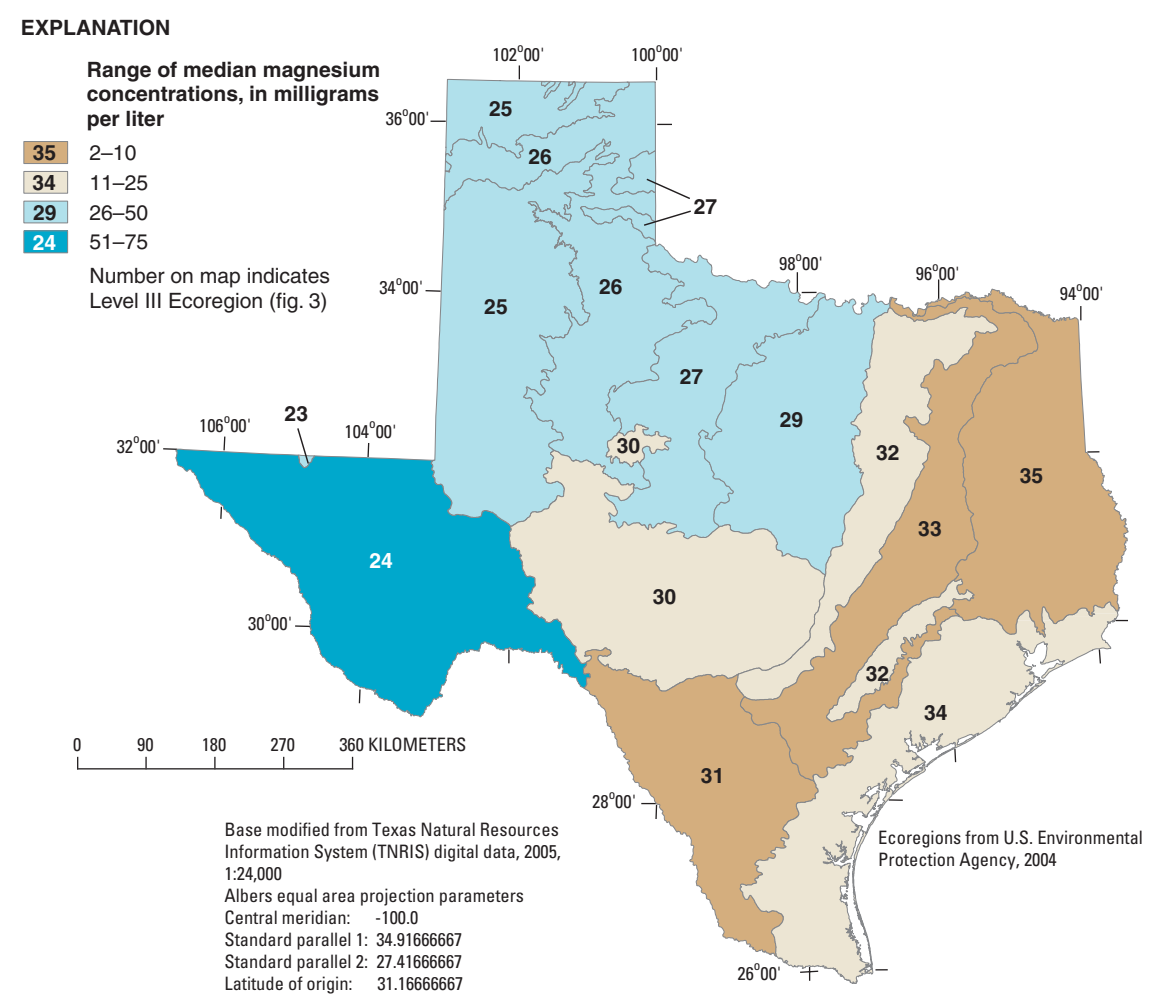

Figure 11. Range of median magnesium concentrations for selected springs in Texas, by ecoregion 


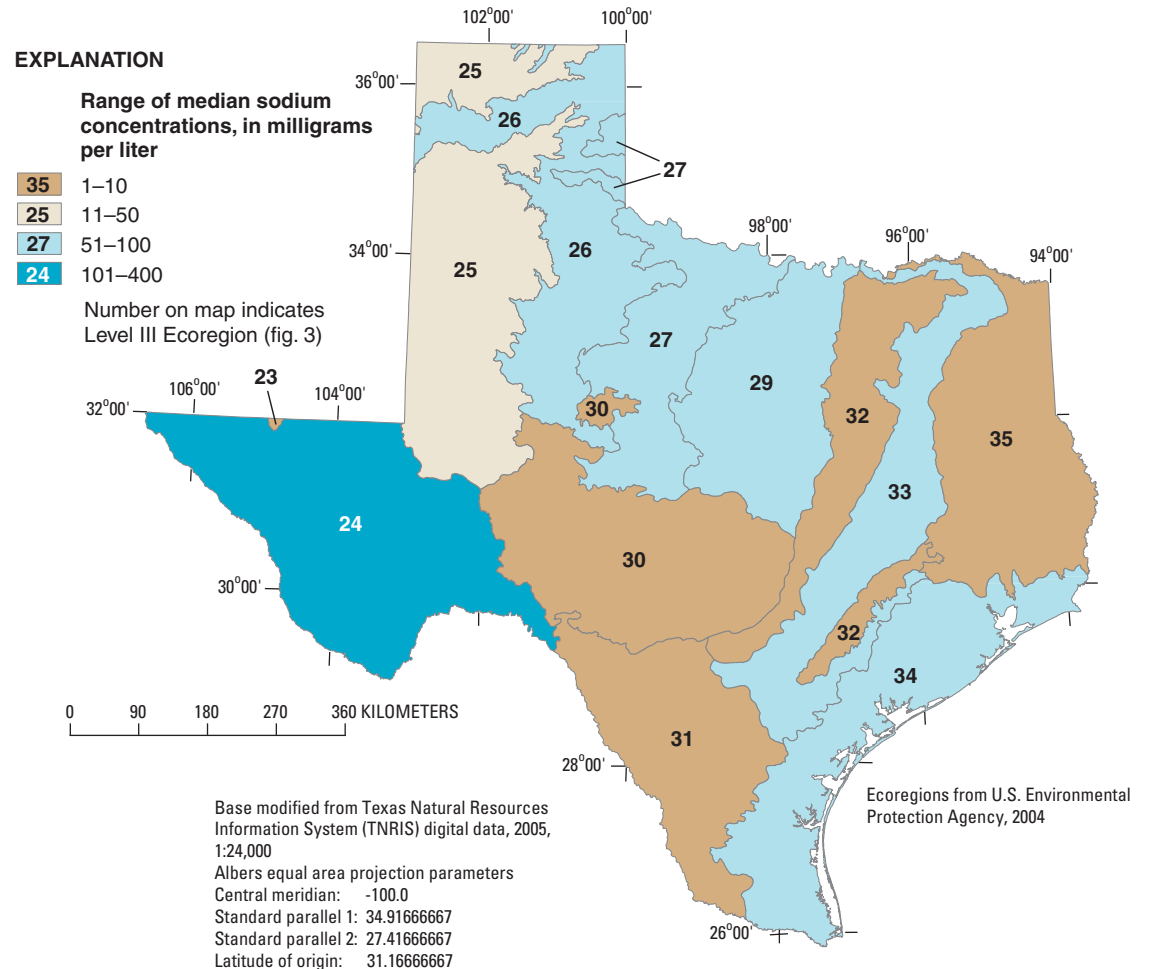

Figure 12. Range of median sodium concentrations for selected springs in Texas, by ecoregion.

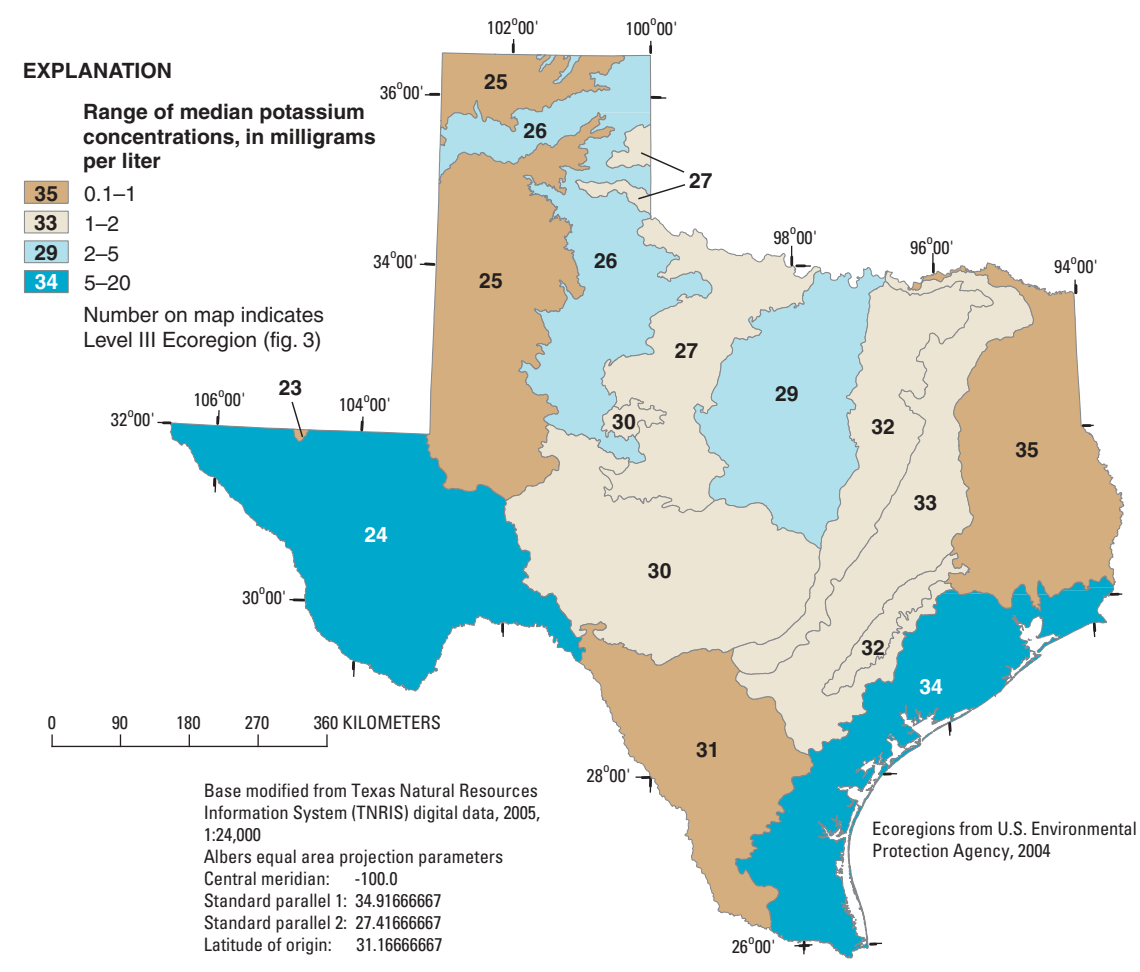

Figure 13. Range of median potassium concentrations for selected springs in Texas, by ecoregion. 


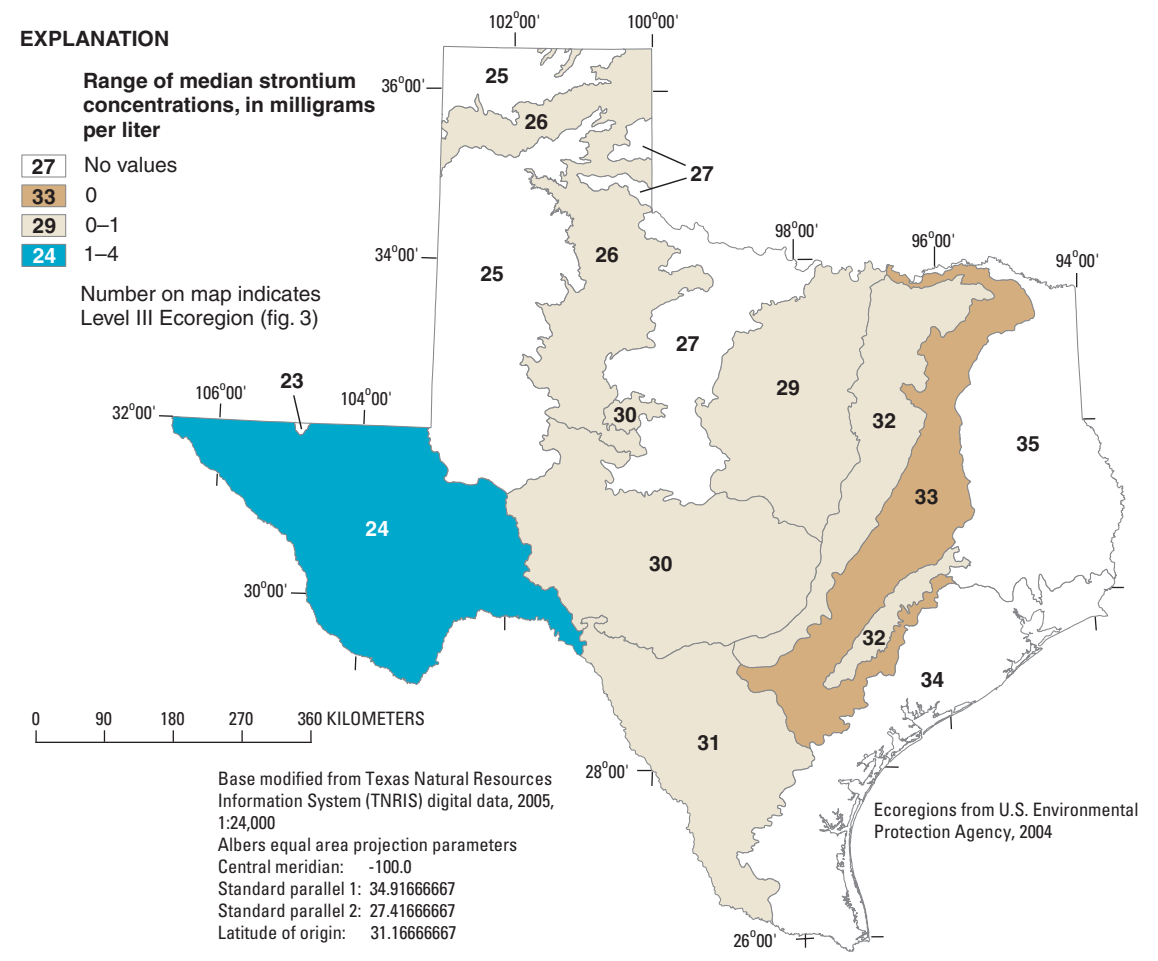

Figure 14. Range of median strontium concentrations for selected springs in Texas, by ecoregion.

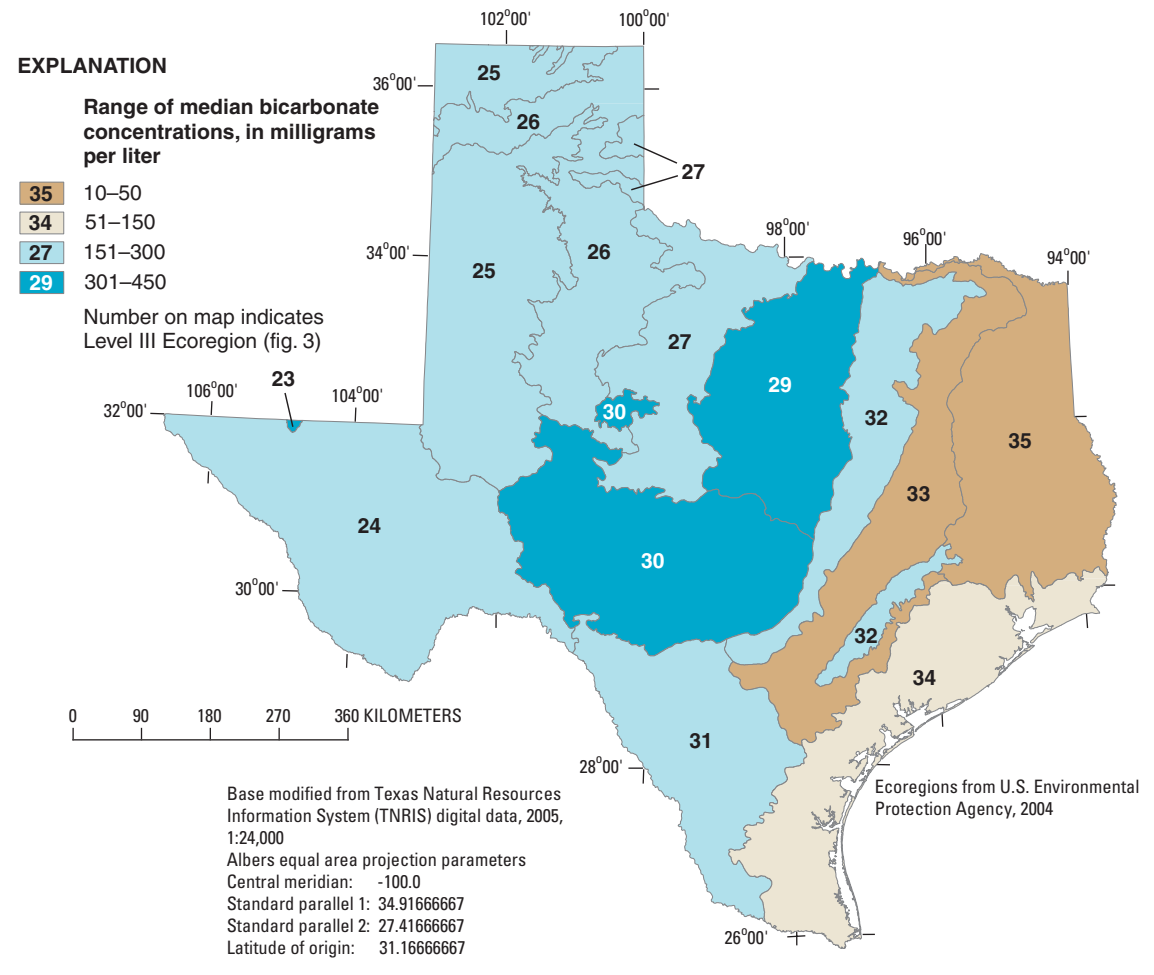

Figure 15. Range of median bicarbonate concentrations for selected springs in Texas, by ecoregion. 


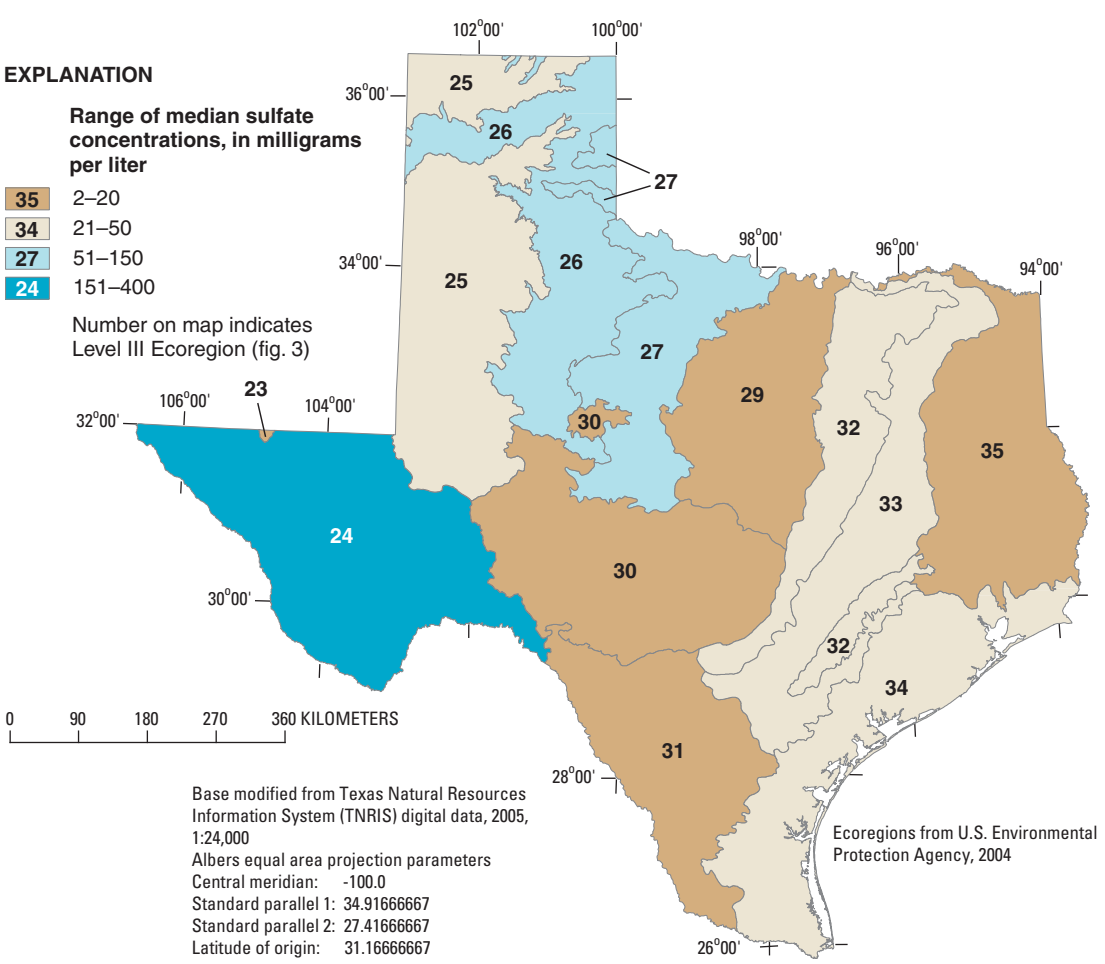

Figure 16. Range of median sulfate concentrations for selected springs in Texas, by ecoregion.

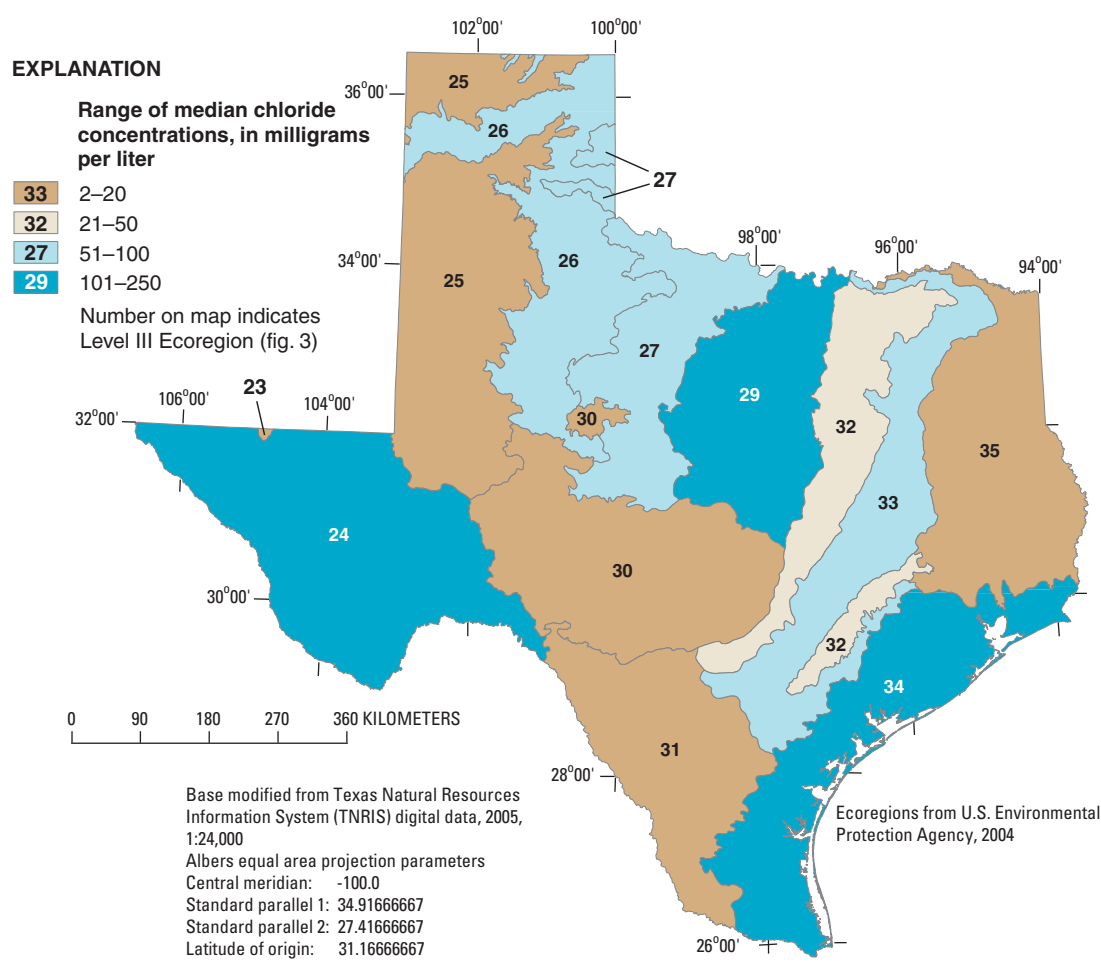

Figure 17. Range of median chloride concentrations for selected springs in Texas, by ecoregion. 


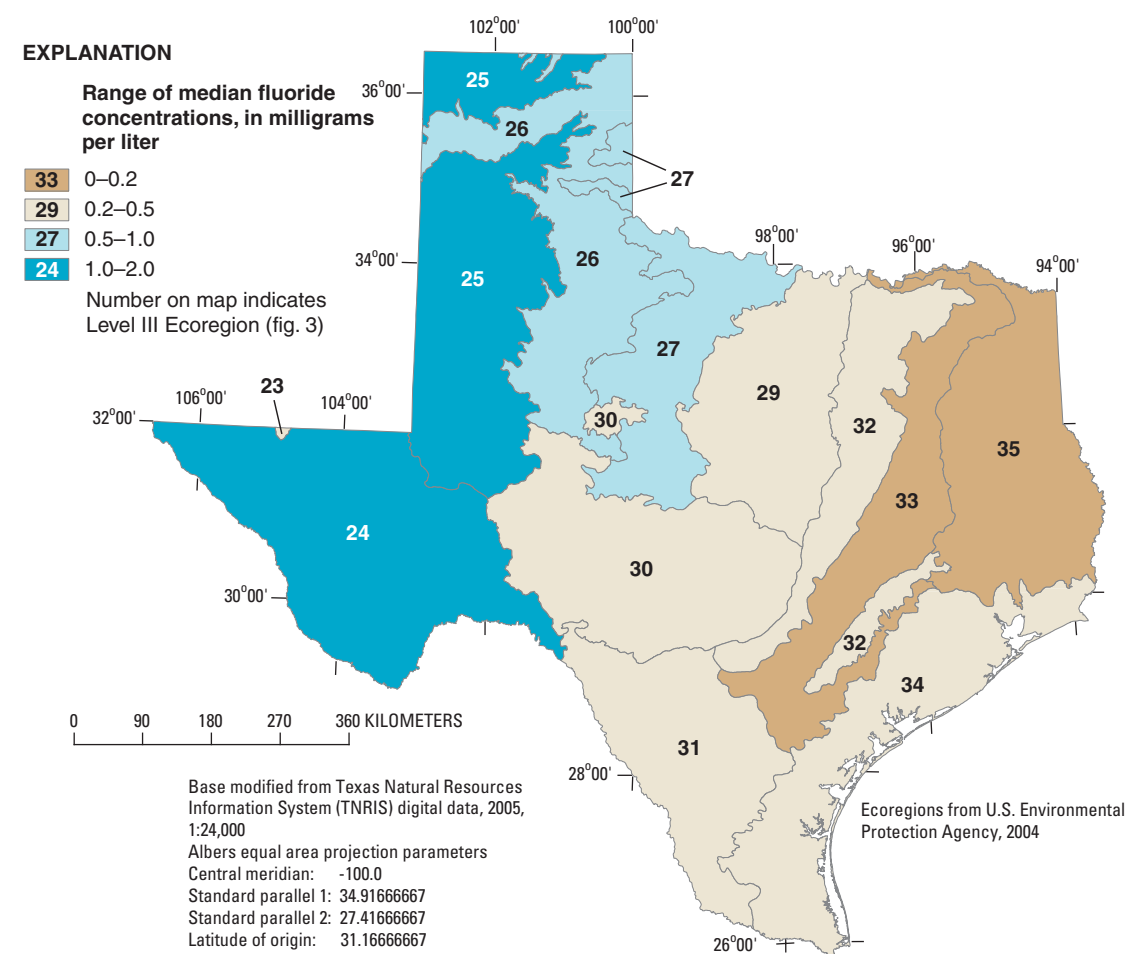

Figure 18. Range of median fluoride concentrations for selected springs in Texas, by ecoregion.

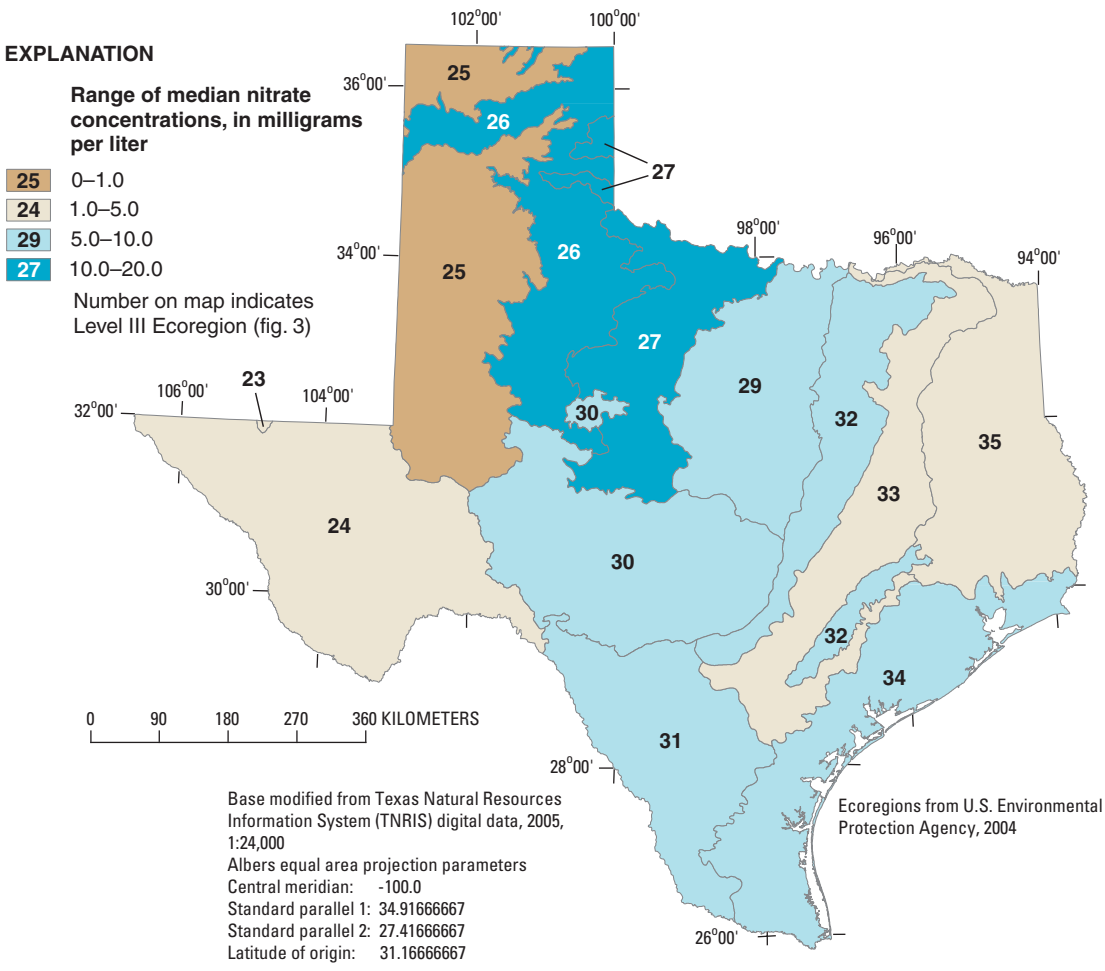

Figure 19. Range of median nitrate nitrogen concentrations for selected springs in Texas, by ecoregion. 


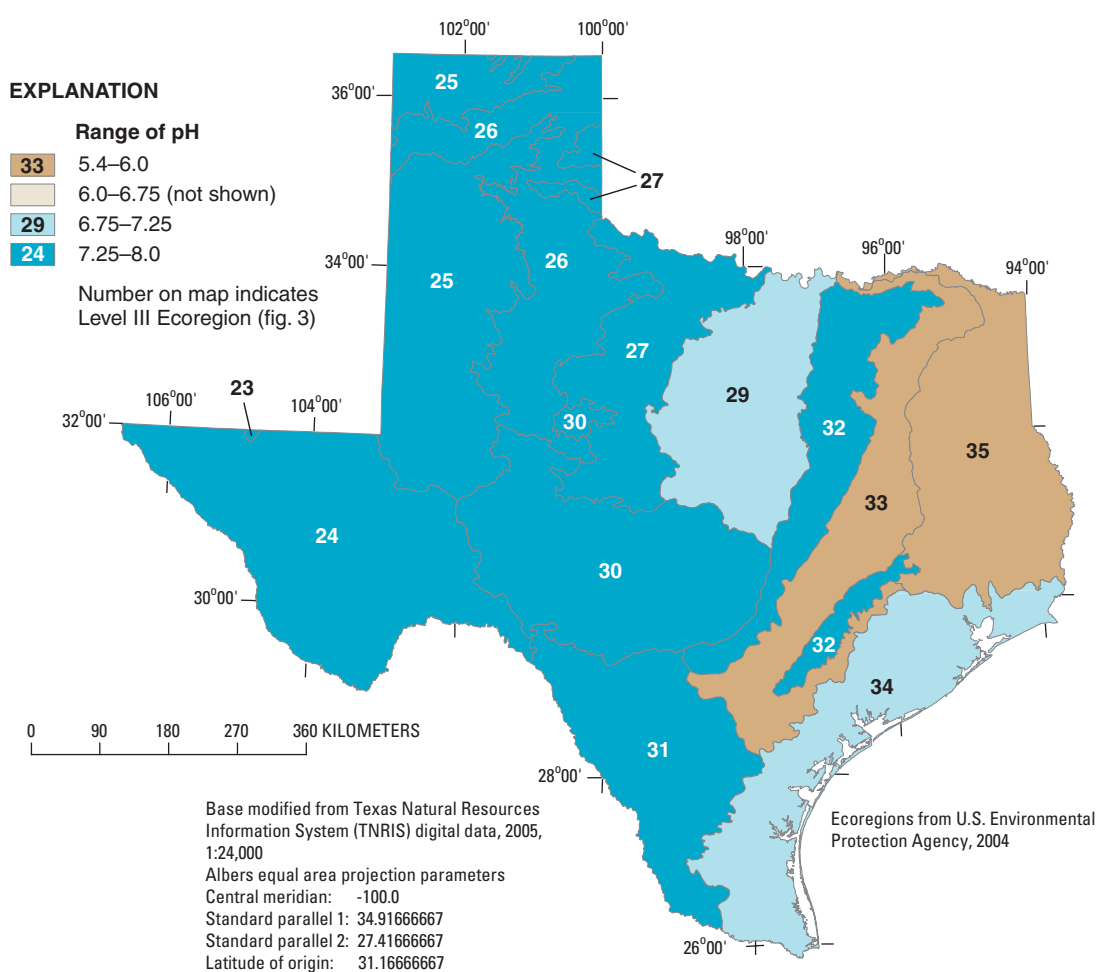

Figure 20. Range of median pH for selected springs in Texas, by ecoregion.

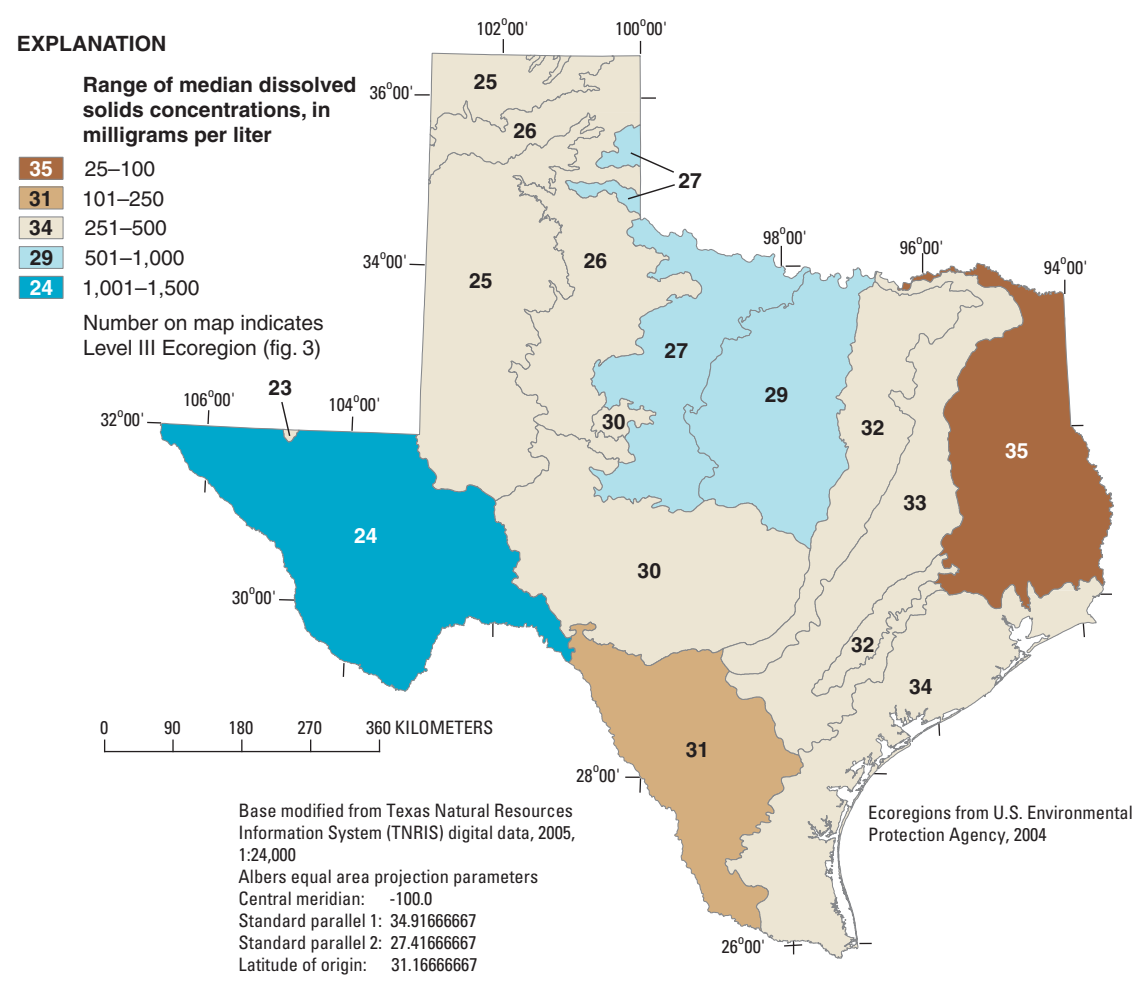

Figure 21. Range of median dissolved solids concentrations for selected springs in Texas, by ecoregion. 


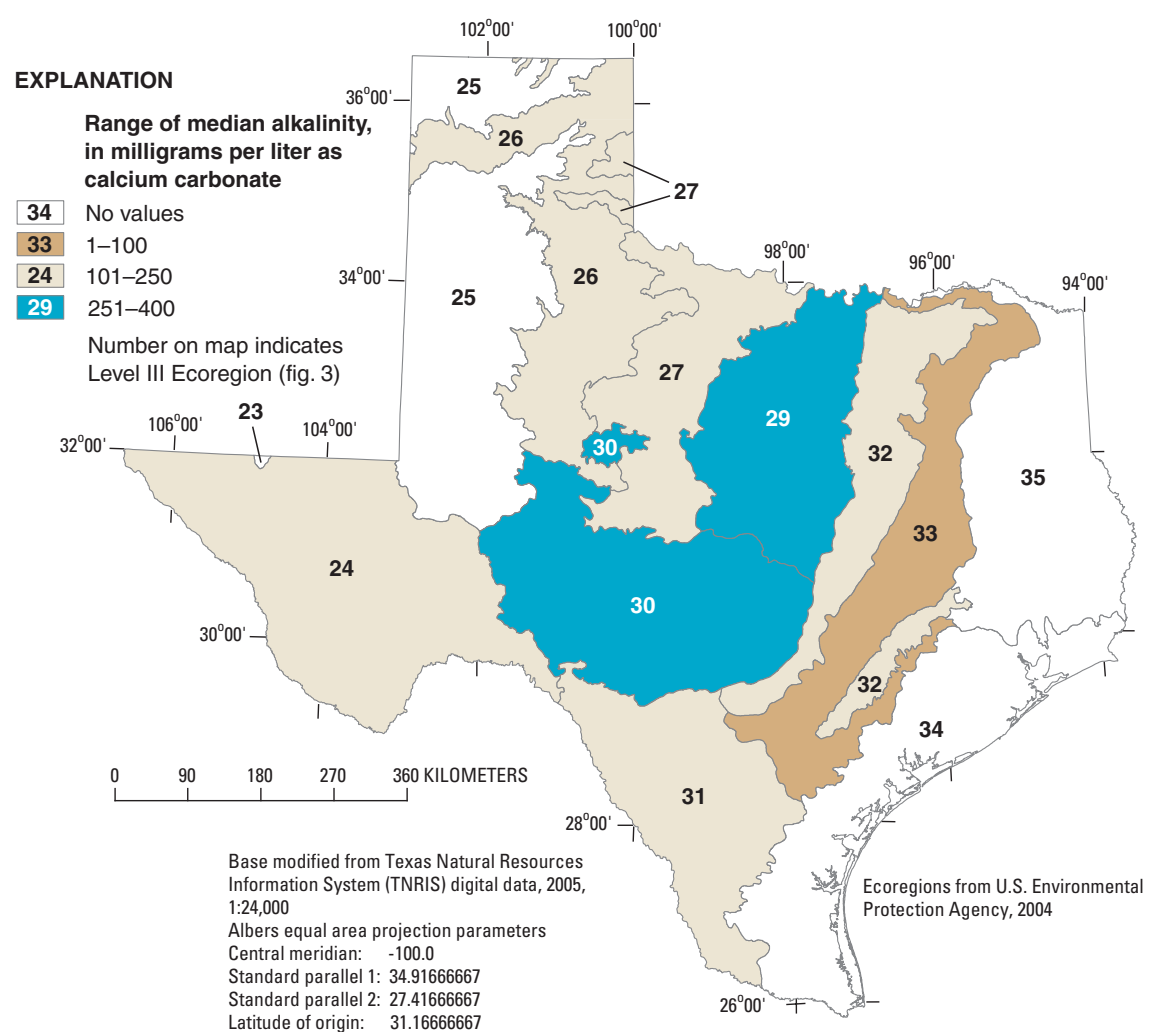

Figure 22. Range of median alkalinity for selected springs in Texas, by ecoregion.

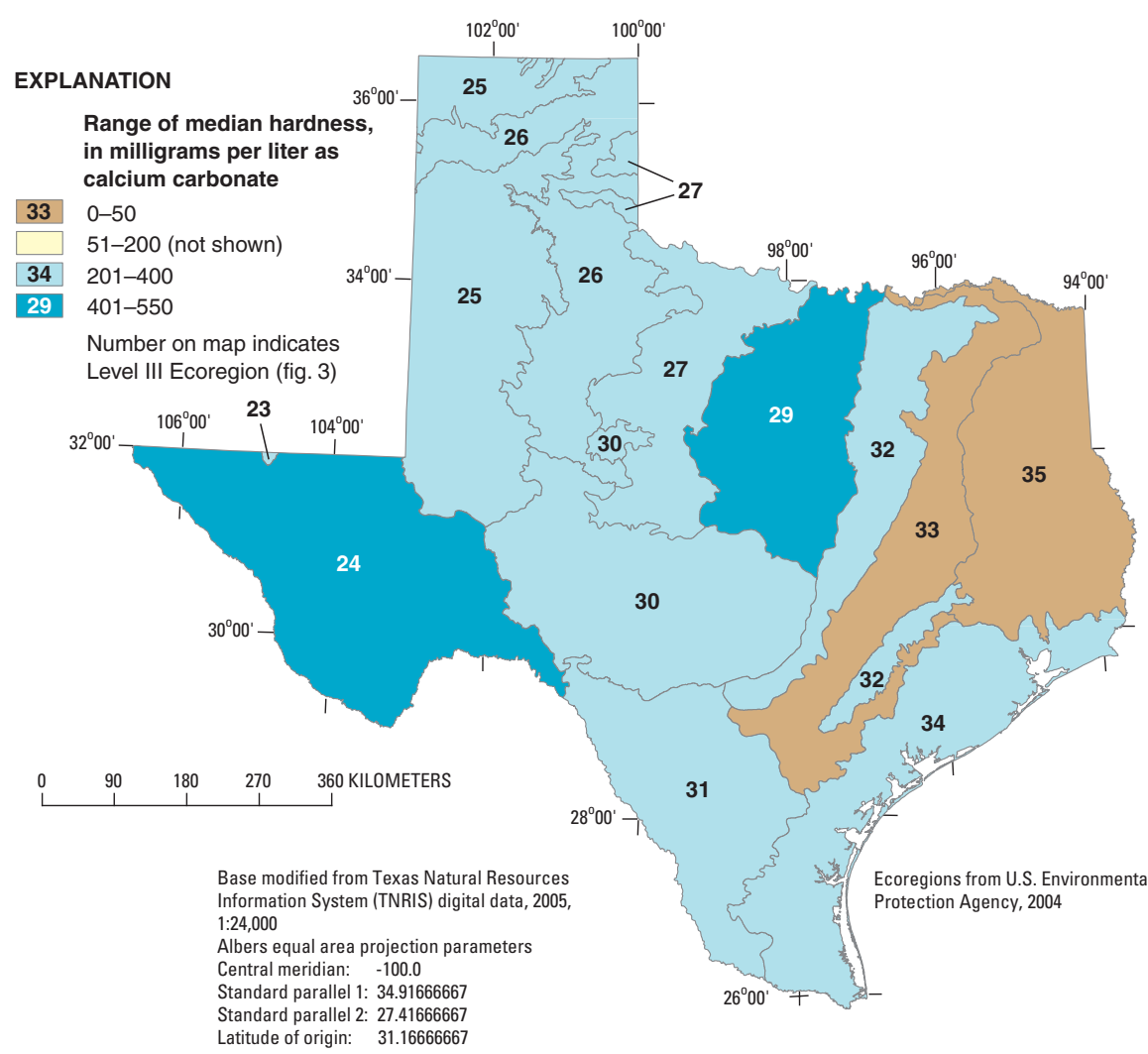

Figure 23. Range of median hardness for selected springs in Texas, by ecoregion. 
EXPLANATION

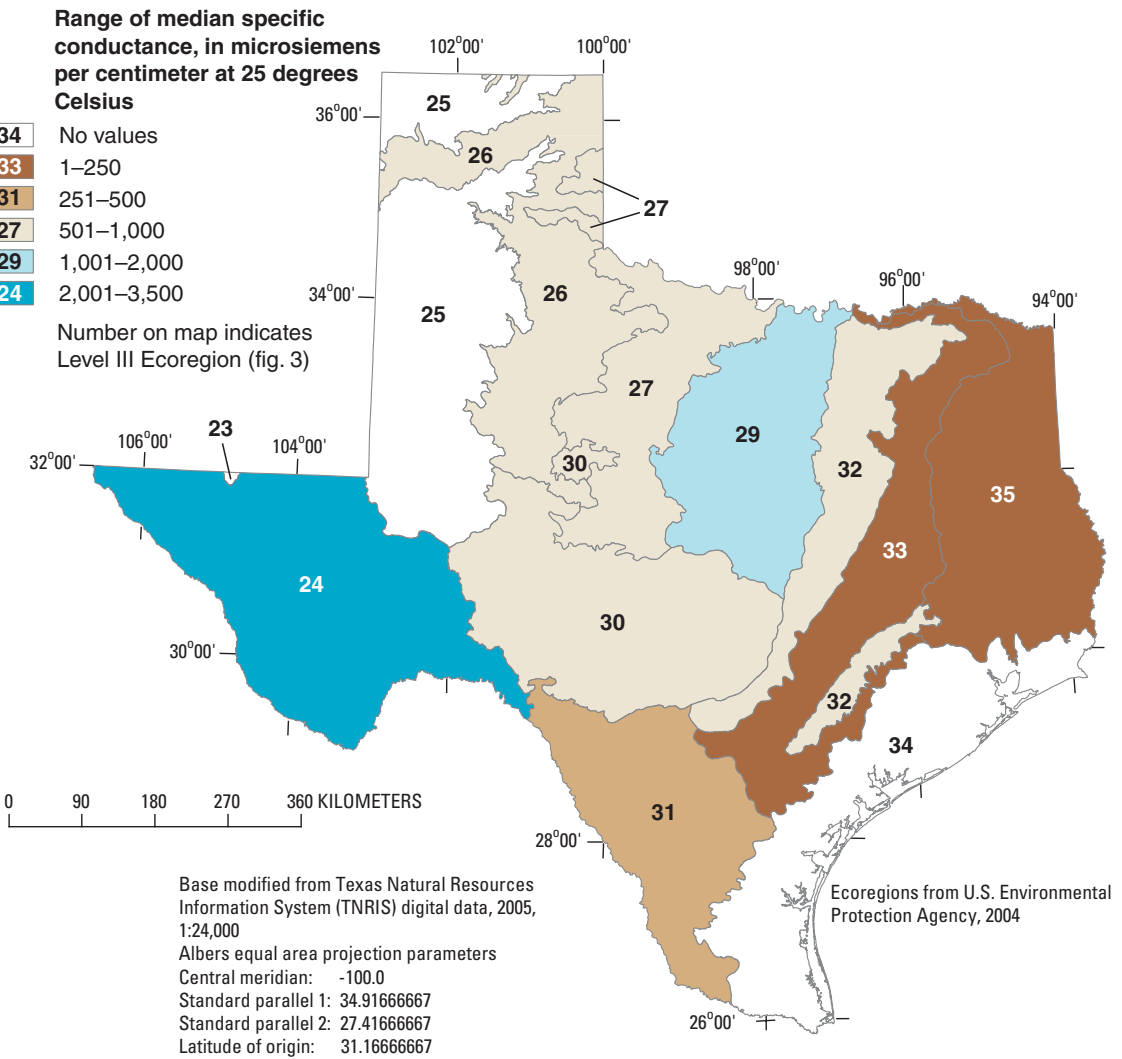

Figure 24. Range of median specific conductance for selected springs in Texas, by ecoregion.

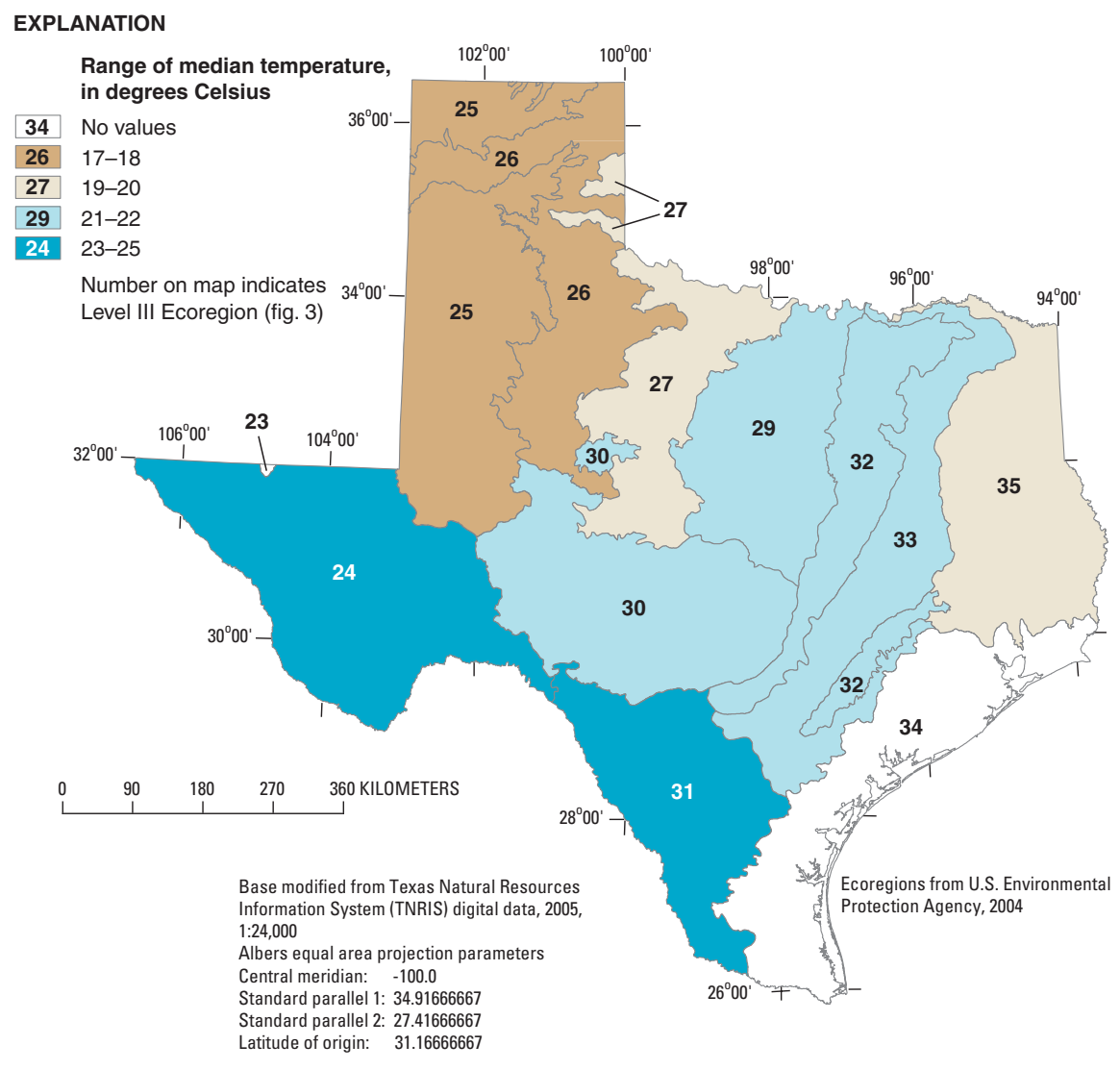

Figure 25. Range of median temperature for selected springs in Texas, by ecoregion. 


\section{High Plains}

The High Plains (Ecoregion 25) is represented by only six springs in the water-quality database because of the small number of springs for this ecoregion in the database. In Texas, the High Plains is noted more for recharge to the Ogallala aquifer than discharge to springs within the boundaries of the ecoregion, although springs associated with the Ogallala aquifer are abundant at the Caprock escarpment in adjacent Ecoregion 26 (fig. 3). Only two of the six springs are well within the boundaries of the High Plains ecoregion; the remaining four springs are at the Caprock escarpment. The few water-quality data for springs in the High Plains indicate that spring flow contains low to moderate concentrations of selected constituents; however, median $\mathrm{pH}(8.0)$ is the highest of any spring in level III ecoregions in Texas. The few data available from the small number of sizeable springs in the High Plains and variability of the data likely do not provide a reliable evaluation of water quality in the ecoregion. A variety of small springs and seeps, many at playa lakes, in the High Plains are listed in Brune (1981).

\section{Southwestem Tablelands}

The Southwestern Tablelands (Ecoregion 26) is represented by 29 springs in the water-quality database. This comparatively large number of springs is attributed to the high spatial density (table 1) of springs along the Caprock escarpment. Many of the springs in the Southwestern Tablelands of Texas flow from the Blaine aquifer and commonly are noted for producing saline water. Other selected springs that flow from the Ogallala aquifer along the Caprock escarpment and from the Seymour aquifer commonly report high salinity and nitrate (nitrogen) concentrations (Ashworth and Hopkins, 1995). Selected springs in the Southwestern Tablelands have the highest or second highest median concentrations of silica (32 milligrams per liter) and nitrate (20 milligrams per liter) of all springs in Texas level III ecoregions.

\section{Central Great Plains}

The Central Great Plains (Ecoregion 27) is represented by 15 springs in the water-quality database. Many of the springs selected for Ecoregion 27 flow from the Ogallala aquifer; others flow from the Seymour aquifer. Springs discharging from the Ogallala aquifer are reported to have high concentrations of calcium and hard waters (Brune, 1981), and parts of the Seymour aquifer have been reported to have high nitrate concentrations (Ashworth and Hopkins, 1995). Median concentrations of silica (34 milligrams per liter), magnesium (35 milligrams per liter), sulfate (112 milligrams per liter), nitrate (12 milligrams per liter), and dissolved solids (670 milligrams per liter) in selected springs of the Central Great Plains are the highest or second highest of any spring in level III ecoregions. Problems associated with springs contributing high concentrations of selected constituents to surface-water bodies in the ecoregion is a watermanagement issue (Ward, 1963). Conversely, the habitats of some inland fish species depend on the maintenance of these same high concentrations (Hubbs and others, 1991).

\section{Cross Timbers}

The Cross Timbers (Ecoregion 29) is represented by 14 springs in the water-quality database. Most of the selected springs in Ecoregion 29 are along the southern boundary with Ecoregions 30 (Edwards Plateau) and 32 (Texas Blackland Prairies) (fig. 3). Springs selected in the southern part of the Cross Timbers flow from aquifers normally associated with the Edwards Plateau and Blackland Prairie, including the Edwards (Balcones fault zone), Ellenburger-San Saba, Marble Falls, and Trinity aquifers. Spring flow from the Ellenburger-San Saba and Marble Falls aquifers can be highly mineralized within short distances of recharge zones (Ashworth and Hopkins, 1995); springs of the Edwards and Trinity aquifers often are hard, alkaline, and have high bicarbonate concentrations. Selected springs in the Cross Timbers have the highest, or second or third highest, median concentrations of calcium (110 milligrams per liter), magnesium (34 milligrams per liter), sodium (83 milligrams per liter), potassium (4.6 milligrams per liter), bicarbonate (410 milligrams per liter), chloride (141 milligrams per liter), dissolved solids (616 milligrams per liter), alkalinity as calcium carbonate (368 milligrams per liter), hardness as calcium carbonate (408 milligrams per liter), and specific conductance $(1,090$ microsiemens per centimeter at 25 degrees Celsius) among springs of all level III ecoregions. The highly variable values are attributed to the difference between the water quality of springs (associated with the Edwards Plateau) in the southern part of the ecoregion and springs in the northern part of the ecoregion. San Saba Springs is represented by 27 sampling visits, greatly influencing summary statistics. Spring flow in the Cross Timbers contributes to base flow of the Trinity, Brazos, and Colorado Rivers.

\section{Edwards Plateau}

The Edwards Plateau (Ecoregion 30) is represented by 88 springs in the water-quality database. This large number is attributed to the high spatial density (table 1) of springs in the ecoregion. Selected springs of the Edwards Plateau issue from the Edwards (Balcones fault zone), Edwards-Trinity (Plateau), Trinity, Ellenburger-San Saba, and Marble Falls aquifers. These carbonate aquifers are associated with hard water and high concentrations of calcium and bicarbonate (Ashworth and Hopkins, 1995). Selected springs in the Edwards Plateau have the second, third, or fourth highest median concentrations of calcium (90 milligrams per liter), bicarbonate (323 milligrams per liter), nitrate (8.1 milligrams per liter), and alkalinity as calcium carbonate (270 milligrams per liter) of all springs in level III ecoregions. Hueco Springs is represented by 92 sampling visits, greatly influencing summary statistics. Spring flow in the ecoregion constitutes the base flow of numerous Texas rivers, including the Colorado, Guadalupe, San Antonio, and Nueces Rivers. 


\section{Compilation of Historical Water-Quality Data for Selected Springs in Texas, by Ecoregion}

\section{Southern Texas Plains}

The Southern Texas Plains (Ecoregion 31) is represented by seven springs in the water-quality database. The small number is attributed to the semiarid climate and flat topography of the ecoregion. Most of the springs selected in the Southern Texas Plains are located along the northern boundary with Ecoregion 30 (Edwards Plateau) (fig. 3) and are associated with the Edwards (Balcones fault zone) and Edwards-Trinity (Plateau) aquifers. Springs are sparse throughout most of the ecoregion; Carrizo Springs is the only spring not associated with the Edwards or Edwards-Trinity aquifers. Selected springs in the Southern Texas Plains have the second, third, or fourth lowest median concentrations of magnesium ( 7 milligrams per liter), sodium (6 milligrams per liter), potassium ( 0.9 milligram per liter), sulfate ( 7 milligrams per liter), chloride (10 milligrams per liter), and dissolved solids ( 245 milligrams per liter) of all springs in level III ecoregions. The largest springs in the ecoregion, San Felipe, Las Moras, and Leona Springs, are represented by 55 sampling visits, greatly influencing summary statistics. Spring flow in the ecoregion contributes to the base flow of the Rio Grande and the Nueces River.

\section{Texas Blackland Prairies}

The Texas Blackland Prairies (Ecoregion 32) is represented by 11 springs in the water-quality database. Similar to Ecoregion 31 (Southern Texas Plains), selected springs of the Texas Blackland Prairies are along the boundary with Ecoregion 30 (Edwards Plateau) and are associated with the Edwards (Balcones fault zone) aquifer. Many of the largest springs in Texas are along the Balcones escarpment separating Ecoregions 30 and 32 (fig. 3), including Comal, San Marcos, Barton, and San Antonio Springs. Selected springs in the Texas Blackland Prairies have median concentrations of selected constituents mostly in the mid-range of median concentrations from selected springs of other level III ecoregions, although the median strontium concentration is the second highest ( 0.7 milligram per liter). Selected springs in Ecoregion 32 have the most waterquality measurements of springs in any Texas ecoregion $(5,387$ individual measurements). The preferential sampling of Barton, Comal, Old Mill, and San Marcos Springs greatly influences summary statistics. Spring flow in the ecoregion contributes a large part of the base flow to numerous Texas rivers, including the Colorado, Guadalupe, and San Antonio Rivers.

\section{East Central Texas Plains}

The East Central Texas Plains (Ecoregion 33) is represented by 15 springs in the water-quality database. Selected springs in the East Central Texas Plains are associated with (roughly from southwest to northeast) the Carrizo-Wilcox, Queen City, Sparta, and Yegua Jackson aquifers. Median concentrations of calcium (14 milligrams per liter), magnesium ( 2 milligrams per liter), bicarbonate (44 milligrams per liter), fluoride ( 0.1 milligram per liter), alkalinity as calcium carbonate (79 milligrams per liter), hardness as calcium carbonate (44 milligrams per liter), and specific conductance (138 microsiemens per centimeter at 25 degrees Celsius) were the lowest or second lowest of all springs in level III ecoregions. Median $\mathrm{pH}$ (5.4) shows spring flow to be somewhat acidic.

\section{Western Gulf Coastal Plain}

The Western Gulf Coastal Plain (Ecoregion 34) is represented by three springs in the water-quality database, each spring separated by a considerable distance. The small number is attributed to the flat topography of the ecoregion. The three selected springs have very little flow and issue from the Gulf Coast aquifer. The few water-quality data for the selected springs indicate that median concentrations of sodium (97 milligrams per liter), potassium (12 milligrams per liter), and chloride (244 milligrams per liter) are the second highest of all springs in level III ecoregions.

\section{South Central Plains}

The South Central Plains (Ecoregion 35) is represented by 14 springs in the water-quality database. Selected springs in the South Central Plains are associated with (roughly from southwest to northeast) the Carrizo-Wilcox, Queen City, Sparta, Yegua Jackson, and Gulf Coast aquifers. Median concentrations of calcium (1 milligram per liter), magnesium (2 milligrams per liter), sodium (4 milligrams per liter), bicarbonate (12 milligrams per liter), sulfate (2 milligrams per liter), chloride (6 milligrams per liter), nitrate ( 1.5 milligrams per liter), dissolved solids (25 milligrams per liter), hardness as calcium carbonate (10 milligrams per liter), and specific conductance (34 microsiemens per centimeter at 25 degrees Celsius) were the lowest or second lowest of all springs in level III ecoregions. Median $\mathrm{pH}$ (5.6) shows spring flow to be slightly acidic

\section{Summary}

A digital database of spring locations and spring-flow measurements in Texas has been recently compiled. Following the publication of this database, a series of stakeholder meetings were held regarding springs in Texas. A need was identified to aggregate water-quality data for a wide variety of Texas springs into a digital database. To address this need, the published database of spring locations and spring-flow measurements was updated, and springs were ranked by mean spring flow for each level III ecoregion in Texas. Springs with the highest mean spring flow in each ecoregion were selected for inclusion in the water-quality database. Additionally, the selection of springs for historical water-quality and spring-flow data entry and analysis was facilitated by a survey mailed to stakeholders across Texas. In total, 232 springs were selected for inclusion in the water-quality database. The springs represent all level III 
ecoregions in Texas, a large percentage of aquifers, and most of the river basins in the State. A brief assessment of the waterquality data for springs in Texas shows that very few data are available in Ecoregions 23 (Arizona/New Mexico Mountains), 25 (High Plains), 33 (East Central Texas Plains), 34 (Western Gulf Coastal Plain), and 35 (South Central Plains). More waterquality data are available for Ecoregions 24 (Chihuahuan Deserts), 30 (Edwards Plateau), and 32 (Texas Blackland Prairies). In general, selected constituent concentrations in Texas springs, including silica, calcium, magnesium, sodium, potassium, strontium, sulfate, chloride, fluoride, nitrate, dissolved solids, and hardness as calcium carbonate, are comparatively high in Ecoregions 24 (Chihuahuan Deserts), 26 (Southwestern Tablelands), 27 (Central Great Plains), and 29 (Cross Timbers), mostly as a result of subsurface geology. In general, comparatively low concentrations of selected constituents in Texas springs are associated with Ecoregions 23 (Arizona/New Mexico Mountains), 31 (Southern Texas Plains), 33 (East Central Texas Plains), and 35 (South Central Plains), closely resembling the water quality of major and minor aquifers in those areas. To more comprehensively assess water quality of springs in Texas, additional data collection and monitoring are needed statewide.

\section{References}

Aragon Long, S.C., Reece, B.D., and Eames, D.R., 2005, Water resources data, Texas, water year 2004-Volumes 1-5: U.S. Geological Survey Water-Data Reports TX-04-1, TX-04-2, TX-04-3, TX-04-4, TX-04-5, accessed October 2005, at http://pubs.usgs.gov/wdr/2004/WDR-TX-04-1/.

Ashworth, J.B., and Hopkins, J., 1995, Major and minor aquifers of Texas: Texas Water Development Board Report 345, $69 \mathrm{p}$.

Baker, E.T., Jr., 2005, Bibliography of ground-water references for all 254 counties in Texas, 1886-2001: U.S. Geological Survey Open-File Report 2005-1270, 321 p., accessed January 2006, at http://pubs.usgs.gov/of/2005/1270/.

Bonacci, O., 1995, Ground water behaviour in karst-Example of the Ombla Spring (Croatia): Journal of Hydrology, v. 165, p. 113-134.

Brannan, D.K., Brannan, C.R., and Lee, T.E., 2003, Reproductive and territorial behavior of Comanche Springs pupfish (Cyprinodon elegans) in San Solomon Spring pool, Balmorhea State Park, Reeves County, Texas: Southwestern Naturalist, v. 48, p. 85-88.

Brune, Gunnar, 1975, Major and historical springs of Texas: Texas Water Development Board Report 189, 95 p.

Brune, Gunnar, 1981, Springs of Texas, volume 1: Fort Worth, Tex., Branch-Smith, Inc., 566 p.

Cartwright, I., Weaver, T., Tweed, S., Ahearne, D., Cooper, M., Czapnik, K., and Tranter, J., 2002, Stable isotope geochemistry of cold $\mathrm{CO}_{2}$-bearing mineral spring waters, Daylesford,
Victoria, Australia-Sources of gas and water and links with waning volcanism: Chemical Geology, v. 185, p. 71-91.

Grasby, S.E., Hutcheon, I., and Krouse, H.R., 2000, The influence of water-rock interaction on the chemistry of thermal springs in western Canada: Applied Geochemistry, v. 15, p. 439-454.

Griffith, G.E., Bryce, S.A., Omernik, J.M., Comstock, J.A., Rogers, A.C., Harrison, B., Hatch, S.L., and Bezanson, D., 2004, Ecoregions of Texas (color poster with map, descriptive text, and photographs): Reston, Va., U.S. Geological Survey, scale 1:2,500,000.

Heitmuller, F.T., and Reece, B.D., 2003, Database of historically documented springs and spring flow measurements in Texas: U.S. Geological Survey Open-File Report 03-315, 4 p., database on CD-ROM.

Hubbs, C., 2001, Environmental correlates to the abundance of spring-adapted versus stream-adapted fishes: Texas Journal of Science, v. 53, p. 299-326.

Hubbs, C., Edwards, R.J., and Garrett, G.P., 1991, An annotated checklist of the fresh-water fishes of Texas, with keys to identification of species: Texas Journal of Science, v. 43, p. 1-56.

Shiner, J.L., 1983, Large springs and early American Indians: Plains Anthropologist, v. 28, p. 1-7.

Texas Water Development Board, 1990, Maps-Major aquifers and minor aquifers: accessed March 2006, at http:// www.twdb.state.tx.us/mapping/index.asp

Texas Water Development Board, 2002, Major Texas rivers: accessed March 2006, at http:// www.twdb.state.tx.us/ mapping/maps/pdf/mtr_34X34.pdf

Texas Water Development Board, 2005, Water Information Integration and Dissemination: accessed October 2005, at http://wiid.twdb.state.tx.us/.

Uliana, M.M., and Sharp, J.M., 2001, Tracing regional flow paths to major springs in Trans-Pecos Texas using geochemical data and geochemical models: Chemical Geology, v. 179 , p. 53-72.

U.S. Environmental Protection Agency, 2004, Level III and IV ecoregions of Texas: Digital data accessed July 2005, at http://ftp.epa.gov/wed/ecoregions/tx/.

U.S. Geological Survey, 2001, USGS water data for the Nation-Surface water: National Water Information System (NWISWeb) at http://waterdata.usgs.gov/nwis/.

Ward, P.E., 1963, Geology and ground-water features of salt springs, seeps, and plains in the Arkansas and Red River Basins of western Oklahoma and adjacent parts of Kansas and Texas: U.S. Geological Survey Open-File Report 63132, 71 p., 3 pls.

William F. Guyton \& Associates, 1979, Geohydrology of Comal, San Marcos, and Hueco Springs: Texas Water Development Board Report 234, 85 p. 


\section{Regional Assessment of Historical Water Quality and Spring Flow for Selected Springs in Texas}

Table 4. Texas springs selected for water-quality and spring-flow database.

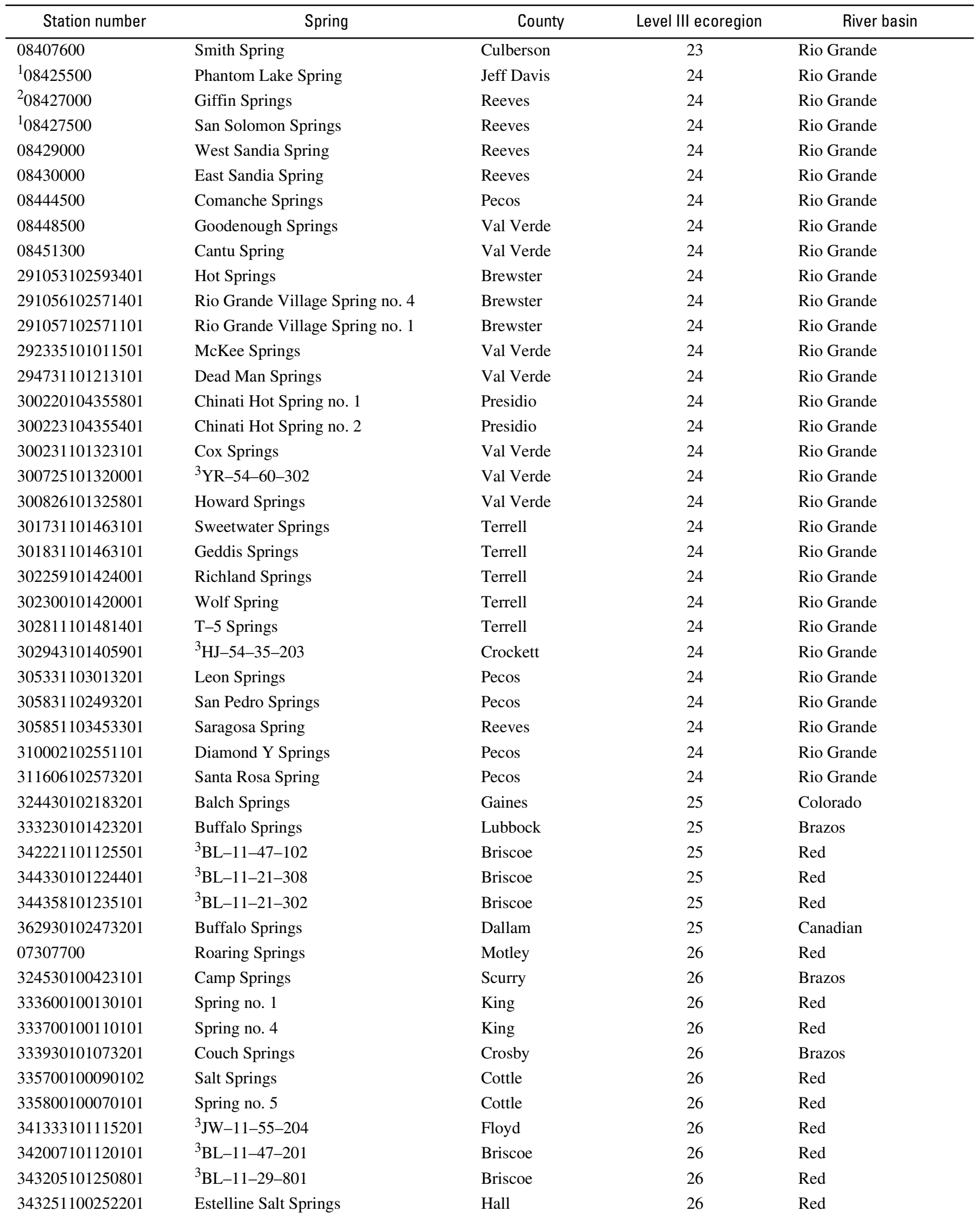


Table 4. Texas springs selected for water-quality and spring-flow database-Continued.

\begin{tabular}{|c|c|c|c|c|}
\hline Station number & Spring & County & Level III ecoregion & River basin \\
\hline 344357101225001 & ${ }^{3} \mathrm{BL}-11-21-306$ & Briscoe & 26 & Red \\
\hline 344409101223901 & ${ }^{3} \mathrm{BL}-11-21-305$ & Briscoe & 26 & Red \\
\hline 344847100471001 & Bitter Creek Springs & Donley & 26 & Red \\
\hline 345034100204801 & Roscoe Springs & Collingsworth & 26 & Red \\
\hline 350213100083001 & ${ }^{3}$ DU-56-39-903 & Collingsworth & 26 & Red \\
\hline 350222100550701 & ${ }^{3}$ JA-55-78-801 & Donley & 26 & Red \\
\hline 350330100083201 & Wolf Springs & Collingsworth & 26 & Red \\
\hline 350551100104501 & ${ }^{3}$ DU-56-32-208 & Collingsworth & 26 & Red \\
\hline 351048100025401 & ${ }^{3}$ DU-55-65-502 & Collingsworth & 26 & Red \\
\hline 351130100113101 & Lehman Springs & Wheeler & 26 & Red \\
\hline 353243100282901 & Fort Elliot Springs & Wheeler & 26 & Red \\
\hline 313132100121701 & Indian Springs & Tom Green & 27 & Colorado \\
\hline 315302099421401 & Pecan Spring & Coleman & 27 & Colorado \\
\hline 332933099460901 & ${ }^{3} \mathrm{RS}-21-34-323$ & Knox & 27 & Brazos \\
\hline 333330098083101 & Buffalo Springs & Clay & 27 & Red \\
\hline 340530098570501 & China Springs & Wichita & 27 & Red \\
\hline 345055100035601 & Sand Springs & Collingsworth & 27 & Red \\
\hline 345920100473001 & ${ }^{3} \mathrm{JA}-12-02-304$ & Donley & 27 & Red \\
\hline 352430100061101 & Wheeler Springs & Wheeler & 27 & Red \\
\hline 353230100073101 & Rathjen Springs & Wheeler & 27 & Red \\
\hline 08103500 & Hannah Springs & Lampasas & 29 & Brazos \\
\hline $08146500^{1}$ & San Saba Springs & San Saba & 29 & Colorado \\
\hline 304313097441101 & Cowan Creek Spring & Williamson & 29 & Brazos \\
\hline 305250097395401 & ${ }^{3} \mathrm{AX}-58-03-911$ & Bell & 29 & Brazos \\
\hline 305317097392401 & ${ }^{3} \mathrm{AX}-58-03-909$ & Bell & 29 & Brazos \\
\hline 305331097403101 & Warwick Springs & Bell & 29 & Brazos \\
\hline 310031097293101 & Childers Springs & Bell & 29 & Brazos \\
\hline 310320098110001 & Hancock Springs & Lampasas & 29 & Brazos \\
\hline 310331098113101 & Swimming Pool Springs & Lampasas & 29 & Brazos \\
\hline 311213098543901 & Baker Spring & San Saba & 29 & Colorado \\
\hline 311632098564401 & Richland Springs & San Saba & 29 & Colorado \\
\hline 311706099003101 & Hall Springs & San Saba & 29 & Colorado \\
\hline 314731097463101 & Pierson Spring & Bosque & 29 & Brazos \\
\hline 321119097342601 & ${ }^{3} \mathrm{PX}-32-52-503$ & Johnson & 29 & Brazos \\
\hline 08127200 & Anson Springs & Tom Green & 30 & Colorado \\
\hline
\end{tabular}




\section{Regional Assessment of Historical Water Quality and Spring Flow for Selected Springs in Texas}

Table 4. Texas springs selected for water-quality and spring-flow database-Continued.

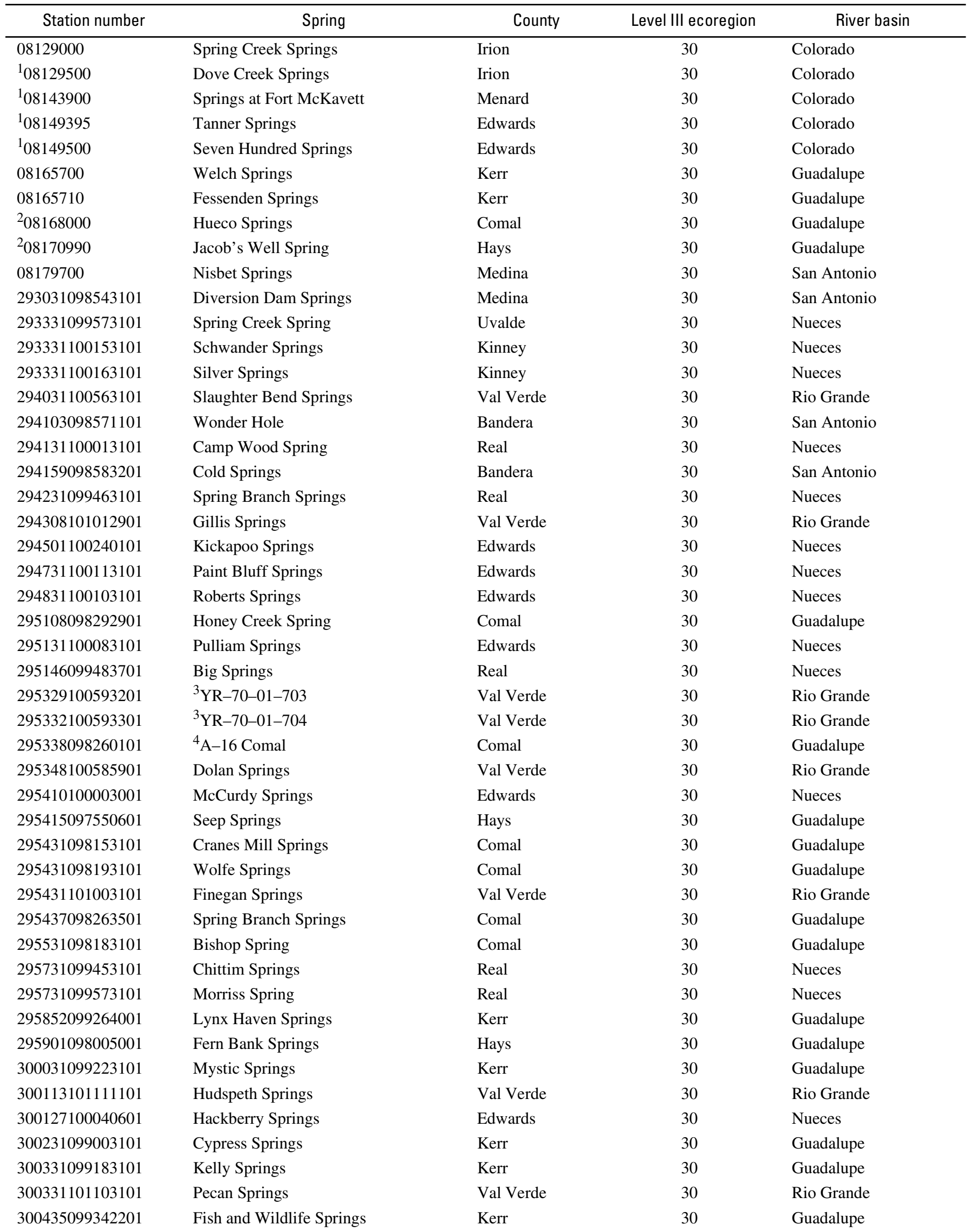


Table 4. Texas springs selected for water-quality and spring-flow database-Continued.

\begin{tabular}{|c|c|c|c|c|}
\hline Station number & Spring & County & Level III ecoregion & River basin \\
\hline 300631099123101 & Goat Springs & Kerr & 30 & Guadalupe \\
\hline 300631099153101 & Henderson Springs & Kerr & 30 & Guadalupe \\
\hline 301002099203401 & Ellebracht Springs & Kerr & 30 & Guadalupe \\
\hline 301031099173101 & Fall Springs & Gillespie & 30 & Guadalupe \\
\hline 301649097464901 & Deep Eddy Spring & Travis & 30 & Colorado \\
\hline 301702099133301 & ${ }^{3} \mathrm{KK}-56-47-701$ & Gillespie & 30 & Colorado \\
\hline 301738097470701 & Power House Spring & Travis & 30 & Colorado \\
\hline 301836099381001 & Water Hole Spring & Kimble & 30 & Colorado \\
\hline 302249099550701 & Coleman Springs & Kimble & 30 & Colorado \\
\hline 302848098084301 & Krause Springs & Burnet & 30 & Colorado \\
\hline 303825099551401 & ${ }^{3} \mathrm{RK}-56-17-801$ & Kimble & 30 & Colorado \\
\hline 304002097450201 & Knight Springs & Williamson & 30 & Brazos \\
\hline 304231099193101 & Kothmann Springs & Mason & 30 & Colorado \\
\hline 304531101413101 & Live Oak Spring & Crockett & 30 & Rio Grande \\
\hline 305528098283001 & Boiling Springs & San Saba & 30 & Colorado \\
\hline 305631099533101 & Wilkinson Springs & Menard & 30 & Colorado \\
\hline 305849098462401 & Heck Springs & San Saba & 30 & Colorado \\
\hline 310812098554201 & Fleming Springs & San Saba & 30 & Colorado \\
\hline 310914098550401 & Sloan Springs & San Saba & 30 & Colorado \\
\hline 310927100074601 & Kickapoo Spring & Tom Green & 30 & Colorado \\
\hline 311028098403801 & Crystal Springs & San Saba & 30 & Colorado \\
\hline 311048098544601 & Hart Spring & San Saba & 30 & Colorado \\
\hline 311101098560101 & Flemming Spring & San Saba & 30 & Colorado \\
\hline 311131100303101 & Mill Spring & Tom Green & 30 & Colorado \\
\hline 311248098594401 & Springs on Maxwell Ranch & San Saba & 30 & Colorado \\
\hline 311506100150401 & Lipan Spring & Tom Green & 30 & Colorado \\
\hline 08204000 & Leona Springs & Uvalde & 31 & Nueces \\
\hline 08452800 & San Felipe Springs & Val Verde & 31 & Rio Grande \\
\hline 08454800 & Mud Springs & Kinney & 31 & Rio Grande \\
\hline 08454890 & Pinto Springs & Kinney & 31 & Rio Grande \\
\hline${ }^{2} 08456300$ & Las Moras Springs & Kinney & 31 & Rio Grande \\
\hline 283031099523101 & Carrizo Springs & Dimmit & 31 & Nueces \\
\hline 291031099543101 & Soldiers Camp Springs & Uvalde & 31 & Nueces \\
\hline 08104300 & Salado Springs & Bell & 32 & Brazos \\
\hline${ }^{2} 08155500$ & Barton Springs & Travis & 32 & Colorado \\
\hline
\end{tabular}




\section{Regional Assessment of Historical Water Quality and Spring Flow for Selected Springs in Texas}

Table 4. Texas springs selected for water-quality and spring-flow database-Continued.

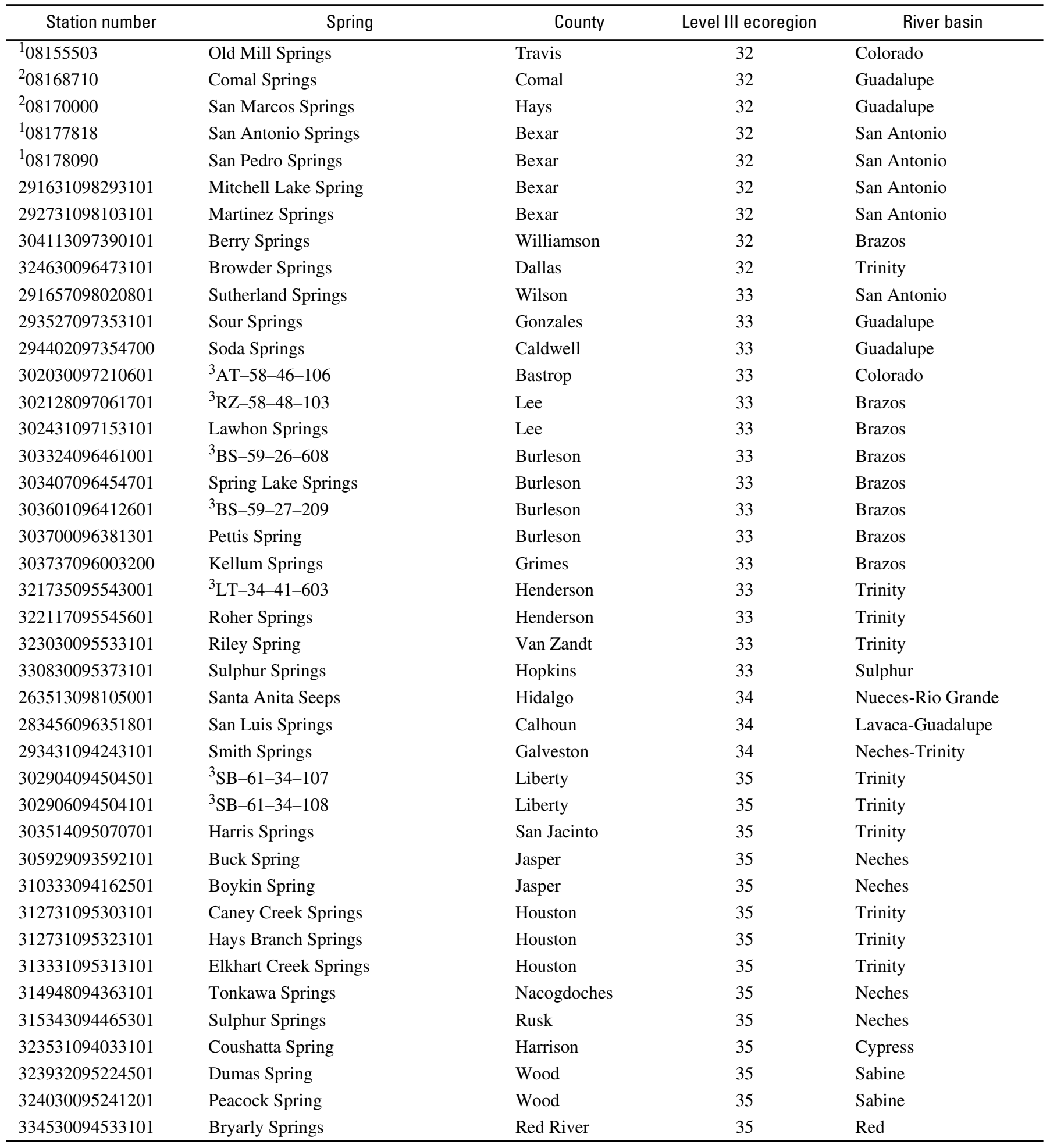

${ }^{1}$ Active partial-record USGS station.

${ }^{2}$ Active continuous USGS station.

${ }^{3}$ Name derived from Texas state well number.

${ }^{4}$ Name from reports of Texas Board of Water Engineers or Texas Water Development Board. 
Table 5. Number of values used to compute mean, median, and standard deviation of selected water-quality constituents and properties for selected springs in Texas, by ecoregion.

[--, no values]

\begin{tabular}{|c|c|c|c|c|c|c|c|c|c|c|c|c|c|c|c|c|c|c|}
\hline $\begin{array}{l}\text { Level III } \\
\text { eco- } \\
\text { region } \\
\text { ID }\end{array}$ & Silica & $\begin{array}{l}\text { Cal- } \\
\text { cium }\end{array}$ & $\begin{array}{l}\text { Mag- } \\
\text { ne- } \\
\text { sium }\end{array}$ & $\begin{array}{c}\text { Sodi- } \\
\text { um }\end{array}$ & $\begin{array}{l}\text { Potas- } \\
\text { sium }\end{array}$ & $\begin{array}{c}\text { Stron- } \\
\text { tium }\end{array}$ & $\begin{array}{c}\text { Bicar- } \\
\text { bo- } \\
\text { nate }\end{array}$ & $\begin{array}{l}\text { Sul- } \\
\text { fate }\end{array}$ & $\begin{array}{l}\text { Chlo- } \\
\text { ride }\end{array}$ & $\begin{array}{l}\text { Fluo- } \\
\text { ride }\end{array}$ & $\begin{array}{c}\text { Nitrate } \\
\text { nitro- } \\
\text { gen }\end{array}$ & $\mathrm{pH}$ & $\begin{array}{l}\text { Dis- } \\
\text { solved } \\
\text { solids }\end{array}$ & $\begin{array}{l}\text { Alka- } \\
\text { linity }\end{array}$ & $\begin{array}{c}\text { Hard- } \\
\text { ness }\end{array}$ & $\begin{array}{l}\text { Spe- } \\
\text { cific } \\
\text { con- } \\
\text { duc- } \\
\text { tance }\end{array}$ & $\begin{array}{l}\text { Tem- } \\
\text { per- } \\
\text { ature }\end{array}$ & Total \\
\hline 23 & 1 & 1 & 1 & 1 & 1 & -- & 1 & 1 & 1 & 1 & 1 & 1 & 1 & -- & 1 & -- & -- & 13 \\
\hline 24 & 115 & 123 & 123 & 119 & 69 & 35 & 156 & 168 & 174 & 67 & 111 & 91 & 150 & 129 & 166 & 159 & 142 & 2,097 \\
\hline 27 & 9 & 14 & 14 & 14 & 2 & -- & 18 & 15 & 16 & 11 & 11 & 14 & 12 & 8 & 14 & 11 & 11 & 194 \\
\hline 29 & 21 & 31 & 31 & 31 & 15 & 3 & 33 & 33 & 33 & 22 & 29 & 25 & 32 & 18 & 32 & 34 & 35 & 458 \\
\hline 30 & 121 & 126 & 124 & 131 & 75 & 33 & 166 & 181 & 195 & 90 & 137 & 109 & 177 & 119 & 199 & 148 & 175 & 2,306 \\
\hline 31 & 32 & 39 & 39 & 39 & 25 & 18 & 40 & 42 & 42 & 29 & 37 & 32 & 41 & 34 & 40 & 33 & 27 & 589 \\
\hline TOTAL & 801 & 460 & 460 & 478 & 254 & 403 & 650 & 1,059 & 1,080 & 311 & 442 & 747 & 948 & 536 & 1,044 & 1,040 & 962 & 11,675 \\
\hline
\end{tabular}

Table 6. Water-quality parameter codes and description of selected constituents and properties used in statistical summaries and maps for selected springs in Texas.

\begin{tabular}{|c|c|c|}
\hline $\begin{array}{l}\text { Constituent } \\
\text { or property }\end{array}$ & $\begin{array}{c}\text { U.S. Geological } \\
\text { Survey } \\
\text { parameter } \\
\text { code }\end{array}$ & Description \\
\hline Silica & 00955 & Silica, water, filtered, milligrams per liter \\
\hline Calcium & 00910 & Calcium, water, unfiltered, milligrams per liter as calcium carbonate \\
\hline Magnesium & 00920 & Magnesium, water, unfiltered, milligrams per liter as calcium carbonate \\
\hline & 00933 & Sodium plus potassium, water, filtered, milligrams per liter as sodium \\
\hline Potassium & 00937 & Potassium, water, unfiltered, recoverable, milligrams per liter \\
\hline Strontium & 01080 & Strontium, water, filtered, micrograms per liter ${ }^{2}$ \\
\hline Bicarbonate & 00440 & Bicarbonate, water, unfiltered, fixed endpoint ( $\mathrm{pH}$ 4.5) titration, field, milligrams per liter \\
\hline Sulfate & 00945 & Sulfate, water, filtered, milligrams per liter \\
\hline $\mathrm{pH}$ & 00403 & pH, water, unfiltered, laboratory, standard units \\
\hline Dissolved solids & 70301 & Residue, water, filtered, sum of constituents, milligrams per liter \\
\hline Alkalinity & 00410 & $\begin{array}{l}\text { Acid neutralizing capacity, water, unfiltered, fixed endpoint ( } \mathrm{pH} 4.5 \text { ) titration, field, milligrams per } \\
\text { liter as calcium carbonate }\end{array}$ \\
\hline Hardness & 00900 & Hardness, water, milligrams per liter as calcium carbonate \\
\hline Specific conductance & 00095 & Specific conductance, water, unfiltered, microsiemens per centimeter at 25 degrees Celsius \\
\hline Temperature & 00010 & Temperature, water, degrees Celsius \\
\hline
\end{tabular}

${ }^{1}$ Sodium summary statistics and maps applied to all values for both parameter codes.

${ }^{2}$ Strontium converted from micrograms per liter to milligrams per liter for analysis. 
Table 7. Mean, median, and standard deviation values of selected water-quality constituents and properties for selected springs in Texas, by ecoregion.

[Values in following order: mean; median; standard deviation from the mean. mg/L, milligrams per liter; na, not applicable; --, no values; $\mu \mathrm{S} / \mathrm{cm}$, microsiemens per centimeter at 25 degrees Celsius; ${ }^{\circ} \mathrm{C}$, degrees Celsius]

\begin{tabular}{|c|c|c|c|c|c|c|c|c|c|}
\hline $\begin{array}{l}\text { Level III } \\
\text { eco- } \\
\text { region } \\
\text { ID }\end{array}$ & $\begin{array}{l}\text { Silica } \\
\text { (mg/L) }\end{array}$ & $\begin{array}{c}\text { Calcium } \\
\text { (mg/L) }\end{array}$ & $\begin{array}{l}\text { Magne- } \\
\text { sium } \\
\text { (mg/L) }\end{array}$ & $\begin{array}{l}\text { Sodium } \\
\text { (mg/L) }\end{array}$ & $\begin{array}{l}\text { Potassium } \\
\text { (mg/L) }\end{array}$ & $\begin{array}{l}\text { Strontium } \\
\text { (mg/L) }\end{array}$ & $\begin{array}{l}\text { Bicar- } \\
\text { bonate } \\
\text { (mg/L) }\end{array}$ & $\begin{array}{l}\text { Sulfate } \\
\text { (mg/L) }\end{array}$ & $\begin{array}{c}\text { Chloride } \\
\text { (mg/L) }\end{array}$ \\
\hline 23 & $10 ; 10 ;$ na & 76; 76; na & $26 ; 26 ;$ na & $2 ; 2 ;$ na & $0.5 ; 0.5 ;$ na & $--;--;--$ & $358 ; 358$; na & $5 ; 5 ;$ na & $2 ; 2 ;$ na \\
\hline 24 & $21 ; 19 ; 8.6$ & $182 ; 177 ; 107$ & $72 ; 73 ; 63$ & $356 ; 390 ; 299$ & $15 ; 17 ; 8.9$ & $3.6 ; 3.4 ; 2.3$ & $258 ; 267 ; 37$ & $497 ; 383 ; 519$ & $389 ; 246 ; 448$ \\
\hline 26 & $35 ; 32 ; 15$ & $178 ; 78 ; 281$ & $33 ; 28 ; 37$ & $543 ; 57 ; 2,398$ & $3.8 ; 3.4 ; 2.7$ & $0.3 ; 0.3 ; 0.08$ & $260 ; 247 ; 91$ & $490 ; 75 ; 1,091$ & 1,$664 ; 69 ; 6,487$ \\
\hline 27 & $29 ; 34 ; 12$ & $214 ; 100 ; 222$ & $63 ; 35 ; 70$ & $299 ; 76 ; 675$ & $1.2 ; 1.2 ; 1.1$ & --; --; -- & $268 ; 259 ; 83$ & $470 ; 112 ; 773$ & $442 ; 56 ; 1,284$ \\
\hline 29 & $11 ; 12 ; 2.0$ & $115 ; 110,35$ & $36 ; 34 ; 16$ & $183 ; 83 ; 265$ & $9.6 ; 4.6 ; 11$ & $0.4 ; 0.4 ; 0.08$ & $395 ; 410 ; 87$ & $18 ; 12 ; 13$ & $326 ; 141 ; 488$ \\
\hline 32 & $12 ; 12 ; 1.2$ & $81 ; 80 ; 7.8$ & $19 ; 17 ; 4.0$ & $14 ; 10 ; 11$ & $1.4 ; 1.4 ; 0.2$ & $0.9 ; 0.7 ; 0.5$ & $295 ; 288 ; 26$ & $29 ; 27 ; 19$ & $28 ; 21 ; 73$ \\
\hline 33 & $46 ; 16 ; 45$ & $23 ; 14 ; 22$ & $5 ; 2 ; 4.0$ & $151 ; 69 ; 248$ & $2.0 ; 1.2 ; 1.8$ & $0.0 ; 0.0 ; 0.01$ & $244 ; 44 ; 411$ & $74 ; 24 ; 87$ & $131 ; 64 ; 195$ \\
\hline 34 & $20 ; 20 ; 11$ & $65 ; 51 ; 29$ & $38 ; 25 ; 41$ & 188; 97; 198 & $12 ; 12 ;$ na & --; --; -- & $262 ; 79 ; 337$ & $86 ; 47 ; 112$ & $298 ; 244 ; 244$ \\
\hline 35 & $23 ; 10 ; 26$ & $1.4 ; 1 ; 1.1$ & $1 ; 2 ; 0.7$ & $7 ; 4 ; 5.9$ & $0.1 ; 0.1 ;$ na & --; --; -- & $45 ; 12 ; 102$ & $6 ; 2 ; 10$ & $14 ; 6 ; 26$ \\
\hline
\end{tabular}

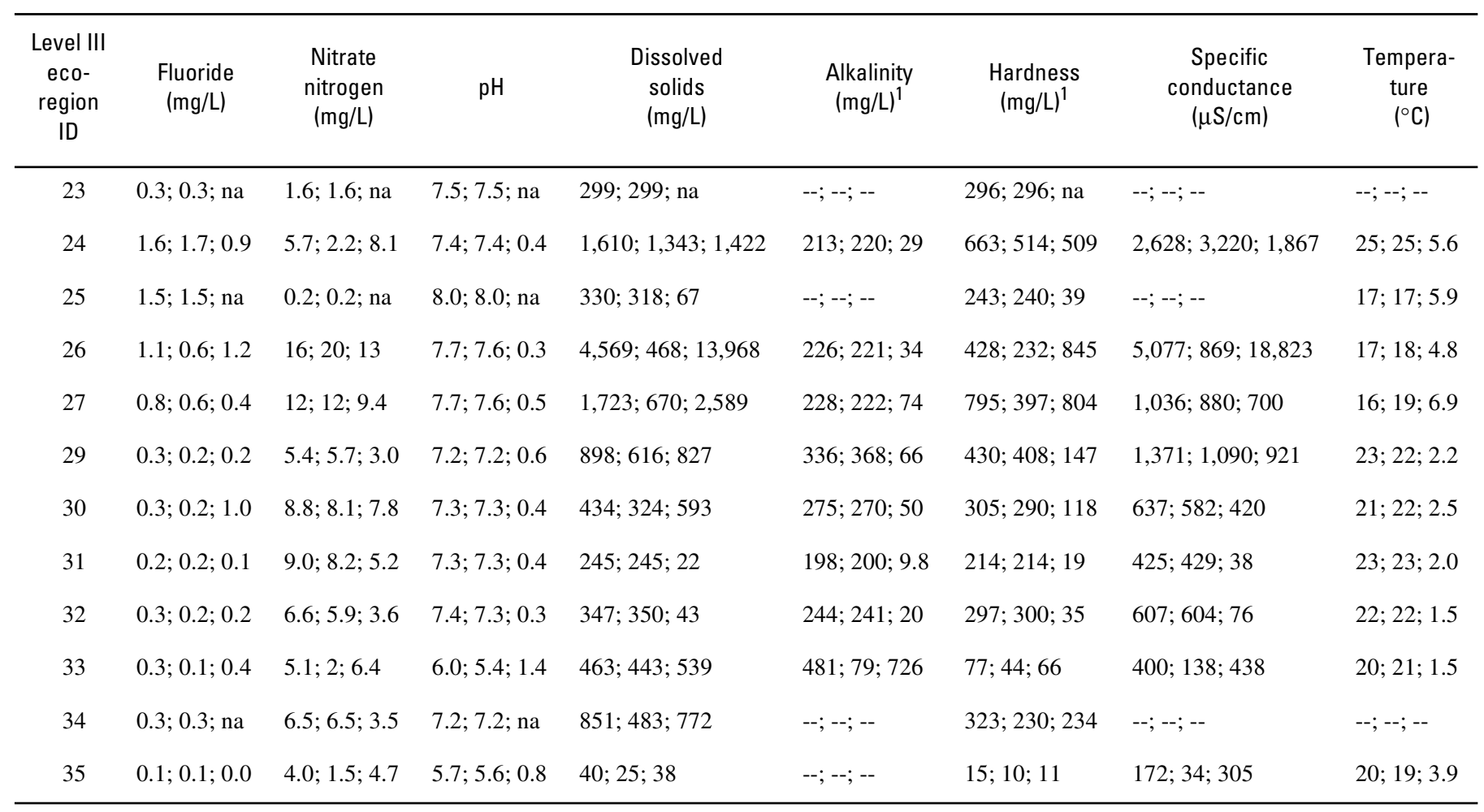

${ }^{1}$ Alkalinity and hardness in milligrams per liter of calcium carbonate. 
Table 8. Minimum and maximum values of selected water-quality constituents and properties for selected springs in Texas, by ecoregion.

[Values in following order: minimum; maximum. mg/L, milligrams per liter; --, no values; $\mu \mathrm{S} / \mathrm{cm}$, microsiemens per centimeter at 25 degrees Celsius; ${ }^{\circ} \mathrm{C}$, degrees Celsius]

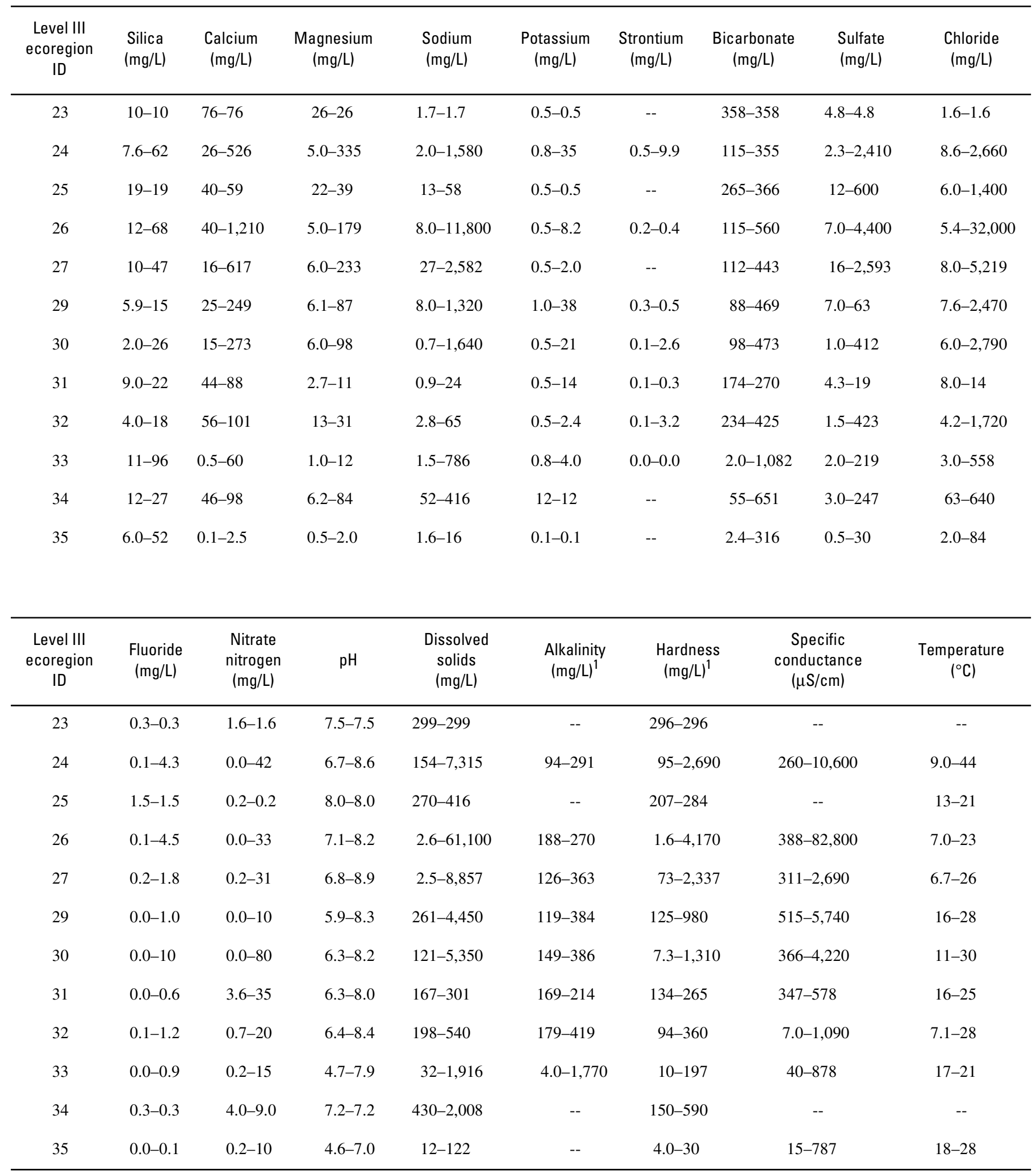

${ }^{1}$ Alkalinity and hardness in milligrams per liter of calcium carbonate. 


\section{Regional Assessment of Historical Water Quality and Spring Flow for Selected Springs in Texas}

Table 9. Water-quality standards of selected constituents and properties.

[mg/L, milligrams per liter; EPA, U.S. Environmental Protection Agency; MCL, maximum contaminant level; NSDWR, National Secondary Drinking Water Regulations; $\mathrm{CCC}$, criterion continuous concentration; $\mathrm{CMC}$, criteria maximum concentration]

\begin{tabular}{|c|c|c|c|}
\hline $\begin{array}{l}\text { Constituent } \\
\text { or property }\end{array}$ & $\begin{array}{c}\text { Standard } \\
\text { concentration }\end{array}$ & Information & Information source \\
\hline Fluoride & $4.0 \mathrm{mg} / \mathrm{L}$ & $\begin{array}{l}\text { EPA MCL }{ }^{1} \text {; potential health effects include bone } \\
\text { disease and mottled teeth (in children) }\end{array}$ & http://www.epa.gov/safewater/mcl.html\#1 \\
\hline Nitrate nitrogen & $10 \mathrm{mg} / \mathrm{L}$ & $\begin{array}{l}\text { EPA MCL }{ }^{1} \text {; potential health effects include } \\
\text { serious illness and possible death for infants } \\
\text { younger than } 6 \text { months }\end{array}$ & http://www.epa.gov/safewater/mcl.html\#1 \\
\hline Fluoride & $2.0 \mathrm{mg} / \mathrm{L}$ & EPA NSDWR $^{2}$ & http://www.epa.gov/safewater/mcl.html\#1 \\
\hline $\mathrm{pH}$ & $6.5-8.5$ & EPA NSDWR $^{2}$ & http://www.epa.gov/safewater/mcl.html\#1 \\
\hline Sulfate & $250 \mathrm{mg} / \mathrm{L}$ & EPA NSDWR $^{2}$ & http://www.epa.gov/safewater/mcl.html\#1 \\
\hline Dissolved solids & $500 \mathrm{mg} / \mathrm{L}$ & EPA NSDWR $^{2}$ & http://www.epa.gov/safewater/mcl.html\#1 \\
\hline Alkalinity & $20 \mathrm{mg} / \mathrm{L}$ & EPA $\mathrm{CCC}^{3}$ & http://www.epa.gov/waterscience/criteria/wqcriteria.html \\
\hline Hardness & $1,000 \mathrm{mg} / \mathrm{L}$ & $\begin{array}{l}\text { Common upper limit for use by chemical } \\
\text { industry }\end{array}$ & http://www.epa.gov/waterscience/criteria/goldbook.pdf \\
\hline
\end{tabular}

\footnotetext{
${ }^{1} \mathrm{MCL}$ is highest level of contaminant allowed in drinking water.

${ }^{2}$ NSDWR is non-enforceable guideline regulating contaminants that might cause cosmetic effects (such as skin or tooth discoloration) or aesthetic effects (such as taste, odor, or color) in drinking water.

${ }^{3} \mathrm{CCC}$ is estimate of highest concentration of a material in surface water to which an aquatic community can be exposed indefinitely without resulting in an unacceptable effect.

${ }^{4} \mathrm{CMC}$ is estimate of highest concentration of a material in surface water to which an aquatic community can be exposed briefly without resulting in an unacceptable effect.
} 